University of Nebraska - Lincoln

DigitalCommons@University of Nebraska - Lincoln

2010

\title{
Microbial reduction of uranium under iron- and sulfate-reducing conditions: Effect of amended goethite on microbial community composition and dynamics
}

H.S. Moon

Princeton University

L. McGuinness

The State University of New Jersey

Ravi K. Kukkadapu

Pacific Northwest National Laboratory, ravi.kukkadapu@pnl.gov

\author{
A.D. Peacock \\ Haley \& Aldrich \\ John Komlos \\ Princeton University, jkomlos@princeton.edu \\ See next page for additional authors \\ Follow this and additional works at: https://digitalcommons.unl.edu/usdoepub \\ Part of the Bioresource and Agricultural Engineering Commons
}

Moon, H.S.; McGuinness, L.; Kukkadapu, Ravi K.; Peacock, A.D.; Komlos, John; Kerkhof, L.J.; Long, P.E.; and Jaffe, Peter R., "Microbial reduction of uranium under iron- and sulfate-reducing conditions: Effect of amended goethite on microbial community composition and dynamics" (2010). US Department of Energy Publications. 174.

https://digitalcommons.unl.edu/usdoepub/174

This Article is brought to you for free and open access by the U.S. Department of Energy at DigitalCommons@University of Nebraska - Lincoln. It has been accepted for inclusion in US Department of Energy Publications by an authorized administrator of DigitalCommons@University of Nebraska - Lincoln. 


\section{Authors}

H.S. Moon, L. McGuinness, Ravi K. Kukkadapu, A.D. Peacock, John Komlos, L.J. Kerkhof, P.E. Long, and Peter R. Jaffe 


\title{
Microbial reduction of uranium under iron- and sulfate-reducing conditions: Effect of amended goethite on microbial community composition and dynamics
}

\author{
H.S. Moon ${ }^{a, e}$, L. McGuinness ${ }^{b}$, R.K. Kukkadapu ${ }^{c}$, A.D. Peacock ${ }^{d}$, J. Komlos ${ }^{a, f}$, \\ L.J. Kerkhof ${ }^{b}$, P.E. Long ${ }^{c}$, P.R. Jaffé $e^{a, *}$ \\ ${ }^{a}$ Department of Civil and Environmental Engineering, Princeton University, Princeton, NJ 08544, USA \\ ${ }^{b}$ Institute of Marine and Coastal Sciences, Cook College, Rutgers, The State University of New Jersey, New Brunswick, NJ 08901, USA \\ ${ }^{c}$ Pacific Northwest National Laboratory, Richland, WA 99352, USA \\ ${ }^{\mathrm{d}}$ Haley \& Aldrich, Inc. Oak Ridge, TN 37830, USA \\ ${ }^{\mathrm{e}}$ Now at School of Earth and Environmental Sciences, Seoul National University, Seoul 151-742, Korea \\ ${ }^{\mathrm{f}}$ Now at Department of Civil and Environmental Engineering, Villanova University, Villanova, PA 19085, USA
}

\section{A R T I C L E I N F O}

Article history:

Received 30 September 2009

Received in revised form

30 April 2010

Accepted 4 May 2010

Available online 26 May 2010

Keywords:

Biostimulation

Groundwater

Uranium

Iron reduction

Sulfate reduction

Geobacter

Goethite

Bioavailable iron

Nanoparticles

\begin{abstract}
A B S T R A C T
There is a growing need for a better understanding of the biogeochemical dynamics involved in microbial U(VI) reduction due to an increasing interest in using biostimulation via electron donor addition as a means to remediate uranium contaminated sites. U(VI) reduction has been observed to be maximized during iron-reducing conditions and to decrease upon commencement of sulfate-reducing conditions. There are many unknowns regarding the impact of iron/sulfate biogeochemistry on $\mathrm{U}(\mathrm{VI})$ reduction. This includes Fe(III) availability as well as the microbial community changes, including the activity of iron-reducers during the uranium biostimulation period even after sulfate reduction becomes dominant. Column experiments were conducted with Old Rifle site sediments containing Fe-oxides, Fe-clays, and sulfate rich groundwater. Half of the columns had sediment that was augmented with small amounts of $\mathrm{Fe}$ (III) in the form of ${ }^{57} \mathrm{Fe}-$ goethite, allowing for a detailed tracking of minute changes of this added phase to study the effects of increased Fe(III) levels on the overall biostimulation dynamics. Mössbauer spectroscopy showed that the added ${ }^{57} \mathrm{Fe}$-goethite was bioreduced only during the first thirty days of biostimultuion, after which it remained constant. Augmentation with Fe(III) had a significant effect on the total flux of electrons towards different electron acceptors; it suppressed the degree of sulfate reduction, had no significant impact on Geobacter-type bacterial numbers but decreased the bacterial numbers of sulfate reducers and affected the overall microbial community composition. The addition of Fe(III) had no noticeable effect on the total uranium reduction.
\end{abstract}

(c) 2010 Elsevier Ltd. All rights reserved.

\section{Introduction}

Uranium contamination of groundwater is of particular concern at many US Department of Energy's (DOE's) sites because oxidized $\mathrm{U}(\mathrm{VI})$ is generally soluble in groundwater, and therefore mobile in the natural environment ( $\mathrm{Gu}$ et al., 2005; Lloyd and Lovley, 2001; Riley et al., 1992). (Bio)-reduction of $\mathrm{U}(\mathrm{VI})$ to $\mathrm{U}(\mathrm{IV})$ is an important reaction influencing

\footnotetext{
* Corresponding author.

E-mail address: jaffe@princeton.edu (P.R. Jaffé).
}

0043-1354/\$ - see front matter @ 2010 Elsevier Ltd. All rights reserved. doi:10.1016/j.watres.2010.05.003 
uranium mobility in a variety of sedimentary environments and is a promising strategy for bioremediation of uraniumcontaminated groundwater (Anderson et al., 2003; Cardenas et al., 2008; Qafoku et al., 2009; Wu et al., 2006). Many laboratory and field studies have shown that the addition of electron donors such as acetate, lactate or ethanol can stimulate the activity of dissimilatory metal-reducing microorganisms, which in turn promotes $\mathrm{U}(\mathrm{VI})$ reduction in contaminated aquifers (Abdelouas et al., 1998; Anderson et al., 2003; Bender et al., 2000; Finneran et al., 2002; Gorby and Lovley, 1992; Istok et al., 2004; Komlos et al., 2008c; Sani et al., 2004; Vrionis et al., 2005; Wu et al., 2006). Enzymatic U(VI) reduction by Desulfovibrio desulfuricans has also been observed (Lovley and Phillips, 1992).

In a previous study at the Old Rifle site, in Colorado (a U.S. Department of Energy Uranium Mill Tailings Remedial Action Site), acetate injection into the aquifer was found to stimulate $\mathrm{Fe}$ (III) reduction and growth of Geobacteraceae (based on aqueous Fe(II) detection in the groundwater and the predominance of Geobacter-like 16S rRNA genes in clone libraries), and a decline in the $\mathrm{U}(\mathrm{VI})$ content of groundwater down-gradient of the injection site (Anderson et al., 2003). Continued acetate addition into the aquifer resulted in a shift in the dominant terminal electron accepting process (TEAP) from Fe(III) reduction to sulfate reduction, which corresponded with a decrease in the rate of removal of soluble U(VI) from groundwater. The shift to sulfate reduction was attributed to consumption of poorly-crystalline Fe(III)-oxide. In contrast, laboratory column experiments using the Rifle sediment and synthetic groundwater with $3 \mathrm{mM}$ acetate but with only little sulfate $(9 \mu \mathrm{M}$; $1000 \times$ less than the Rifle groundwater), indicated that a significant amount of $\mathrm{Fe}$ that exists as goethite is bioavailable for extended period of times (Komlos et al., 2008c). Similar column experiments but with comparable sulfate levels as in the field, showed that sulfate reduction did not negatively affect U(VI) removal (Komlos et al., 2008b; Moon et al., 2009). These results indicate that the maintenance of biological Fe(III) reduction can (but does not necessarily have to) be essential for sustaining $\mathrm{U}(\mathrm{VI})$ bioreduction, hence the effect of the change from iron to sulfate reduction as the dominant TEAP on U(VI) reduction needs to be better understood.

Although the utilization of terminal electron acceptors is often assumed to be sequential from the highest to the lowest energy yield, and spatial and temporal zonation of terminal electron accepting processes are commonly modeled as such (Kindred and Celia, 1989; Mohanty et al., 2008; Rabouille and Gaillard, 1991; Smith and Jaffe, 1998; Wang et al., 2003; Yabusaki et al., 2007), iron and sulfate reduction have often been observed to occur concurrently. In a rigorous analysis of the concurrent reduction of Fe(III) and sulfate (Postma and Jakobsen, 1996), it was shown that zonation between Fe(III) and sulfate reduction is much better explained via a partial equilibrium approach. Their approach gives a theoretical foundation explaining why in the presence of multiple iron minerals, simultaneous $\mathrm{Fe}(\mathrm{III})$ and sulfate reduction is possible under a wide range of environmental conditions, and that in the presence of highly bioavailable (or less stable) Fe(III) phases, such as amorphous $\mathrm{Fe}(\mathrm{OH})_{3}$, iron reduction is favored, while as the stability of iron phases increases, sulfate reduction is favored. Therefore, during biostimulation, a sediment with an increased bioavailable iron content should enhance iron reduction relative to sulfate reduction, while this bioavailable Fe(III) phase is being reduced. It is unclear if this will have an effect on $\mathrm{U}(\mathrm{VI})$ reduction and how it will affect the microbial community throughout the biostimulation process.

Based on observations from current understanding of iron, sulfate, and uranium reduction processes, as well as recent results from laboratory and field-scale biostimulation experiments, the specific objectives of this research were to determine how an increase in bioavailable Fe(III) affects: i) the iron and sulfate reduction dynamics during biostimulation, including the overall utilization of the electron donor and electron acceptor; ii) the microbial community during the whole biostimulation process; and iii) uranium bioreduction.

To answer these specific questions, a series of biostimulation column experiments were conducted with old Rifle site sediments and groundwater, with and without amendment of small amounts of small-particle $(<10-\mathrm{nm})$ ${ }^{57} \mathrm{Fe}$-goethite to continuously track minute changes in the spiked ${ }^{57} \mathrm{Fe}$-goethite (and native Fe-minerals), particularly during strong sulfate reduction. Effluent chemistry as well as extractable solid species were monitored for the goethite amended and non-amended columns over time. At the same time, the change of the microbial community structure and the activity of iron-reducing bacteria in the goethite amended and non-amended sediments was tracked throughout the biostimulation period by using TRFLP (terminal restriction fragment length polymorphism) analysis of DNA and RNA, in addition to qPCR (quantitative polymerase chain reaction) analysis in order to determine the effect on the microbial dynamics due to the spiked ${ }^{57} \mathrm{Fe}$-goethite. The advantage of using ${ }^{57} \mathrm{Fe}$-goethite as the source of the added Fe(III) phase is that it will allow for a very accurate quantification throughout the biostimulation process of the reduction of this specific phase, and also allow for it's reduction to be linked to changes in the microbiological and chemical dynamics.

\section{Materials and methods}

\subsection{Column design and operation}

A total of seven glass columns $(15 \mathrm{~cm}$ long, $2.6 \mathrm{~cm}$ in diameter, with a $0.2 \mu \mathrm{m}$ outflow filter plate, Kimble Kontes) were wet packed with $150( \pm 15) \mathrm{g}$ of $<2 \mathrm{~mm}$ sieved and well mixed sediment from an area of the Old Rifle site with relatively low current uranium concentration in groundwater. This sediment was designated Rifle Area Background Sediment (RABS). A description of the sediment and groundwater can be found in (Anderson et al., 2003; Komlos et al., 2008c; Yabusaki et al., 2007). The previously water-saturated sediment was stored at $4{ }^{\circ} \mathrm{C}$ without any further treatment before use. A second set of seven columns were packed at the same time with the same sediment, except the sediment was augmented with ${ }^{57} \mathrm{Fe}$ (0.12-0.15 wt\%) as ${ }^{57} \mathrm{Fe}$-goethite. The synthetic ${ }^{57} \mathrm{Fe}$-goethite was made in the laboratory as described by (Schwertmann and Cornell, 1991). Mössbauer spectroscopy and powder XRD (X-ray diffraction) indicated that the average particle size of ${ }^{57} \mathrm{Fe}$-goethite is $<10 \mathrm{~nm}$. It displays a doublet at RT sextet at 
$4.5 \mathrm{~K}$ (not shown), with parameters similar to those described by (van der Zee et al., 2003).

Groundwater from the Old Rifle site (which contains ca. $9 \mathrm{mM}$ of sulfate but was amended with $20 \mu \mathrm{M} \mathrm{U}(\mathrm{VI})$ ) was pumped upflow through each of the columns at a rate of $0.035 \mathrm{ml} / \mathrm{min}$, resulting in a hydraulic residence time of $12 \mathrm{~h}$ and a linear velocity of $30 \mathrm{~cm} /$ day, which is the same as the velocity under field-scale biostimulation. The dispersivity was estimated from a tracer test as $0.81 \mathrm{~cm}$. The influent media was continuously purged with $\mathrm{N}_{2}$ gas to remove the dissolved oxygen (DO) from the influent. Biostimulation began by pumping acetate via syringe pumps (KD Scientific) into the main influent line, just before the column influent, resulting in an acetate concentration of $3 \mathrm{mM}$ after mixing with the influent media. This acetate concentration was the same as used in previous column experiments (Komlos et al., 2008a, 2008b, 2008c; Moon et al., 2007, 2009) as well as at the old Rifle field site during biostimulation (Anderson et al., 2003), and will therefore result in microbiological dynamics that represent biostimulation and not natural background conditions. The columns were biostimulated for 100 days at $17^{\circ} \mathrm{C}$. Each column was destructively sampled at 10-20 day intervals in an anaerobic glove box (3\%: $97 \% \mathrm{H}_{2}: \mathrm{N}_{2}$ ) as described by (Moon et al., 2009). The sediments were divided into the bottom third, middle third, and top third of the column. Each of these three fractions was then homogenized, after which each homogenized fraction was analyzed for solid phase $\mathrm{U}$ and $\mathrm{Fe}$, as well as the microbial community analysis described below. Columns resided in the glove box for less than an hour during the time sediments were processed. Sediments used for microbiological characterization were placed immediately in liquid nitrogen and then stored in $\mathrm{a}-80^{\circ} \mathrm{C}$ freezer until further analysis.

\subsection{Analytical measurements}

Column effluent concentrations were monitored for acetate, Fe (II), U(VI), and sulfate during the biostimulation period. Effluent $\mathrm{Fe}$ (II) concentrations were measured by adding $0.5 \mathrm{~mL}$ of effluent solution to $0.5 \mathrm{~mL}$ of $1 \mathrm{~N} \mathrm{HCl}$ and analyzed after $1 \mathrm{~h}$ using the ferrozine assay (Lovley and Phillips, 1987b). Acetate and sulfate were analyzed using a Dionex DX500 ion chromatograph equipped with a CD25 conductivity detector and a Dionex IonPac AS14-4 mm column. Influent and effluent U (VI) concentrations were analyzed using reversed phased chromatography coupled to post column derivatization with the dye Arsenazo III (Sigma-Aldrich) as described by (Lack et al., 2002). The sediment-associated uranium was extracted from the biostimulated sediment by adding 2-3 g of sediment to $5 \mathrm{~mL}$ of $1 \mathrm{M} \mathrm{NaHCO}_{3}$ and letting the extraction proceed under aerobic conditions for four days (Moon et al., 2009). All samples were filtered $(0.2 \mu \mathrm{m})$ and stored at $4{ }^{\circ} \mathrm{C}$ until analyzed.

Biogenic Fe(II) was measured at the termination of the column experiments in an anaerobic glove box $\left(3 \%: 97 \% \mathrm{H}_{2}: \mathrm{N}_{2}\right)$ by adding $0.2-0.3 \mathrm{~g}$ of sediment to $5 \mathrm{~mL} 0.5 \mathrm{~N} \mathrm{HCl}$, extracting for $24 \mathrm{~h}$ (Komlos et al., 2008c; Kukkadapu et al., 2006) and detecting as described above. The $\mathrm{HCl}$ extractable Fe(total) concentration was determined using the same procedure as the $24 \mathrm{~h} 0.5 \mathrm{~N} \mathrm{HCl}$ extractable Fe(II) procedure except $0.2 \mathrm{~mL}$ of $0.25 \mathrm{~N}$ hydroxylamine hydrochloride was added to reduce any extractable $\mathrm{Fe}(\mathrm{III})$ to $\mathrm{Fe}(\mathrm{II})$.

\section{3. $\quad{ }^{57} \mathrm{Fe}-\mathrm{Mössbauer}$ spectroscopy}

Mössbauer analysis of the pristine sediment and synthetic ${ }^{57} \mathrm{Fe}$-goethite was performed on an air-dried sample, while those of biostimulated sediments were performed on samples that were dried in an anoxic chamber. The prepared Mössbauer disks were stored in an anoxic chamber until analysis. Spectra were obtained at various temperatures, room temperature (RT) to liquid He $(4.2 \mathrm{~K})$, but only select spectra obtained at $200-\mathrm{K}$ are shown here. A closed-cycled cryostat (ARS, Allentown) was employed for low temperature measurements. Details of the Mössbauer instrumentation, sample preparation procedure, and guidelines for modeling were reported in (Kukkadapu et al., 2006).

\subsection{DNA extraction and purification}

Genomic DNA was extracted from sediment samples by a modified phenol chloroform ethanol extraction protocol (Kerkhof and Ward, 1993). The DNA was quantified by image analysis (Kerkhof and Kemp, 1999) on a 1\% agarose gel on the Gel Logic 100 Imaging System (Carestream Molecular Imaging, Rochester, NY) and 100 ng was loaded into a cesium chloride solution $(1 \mathrm{~g} / \mathrm{ml}$ ) for density gradient DNA purification.
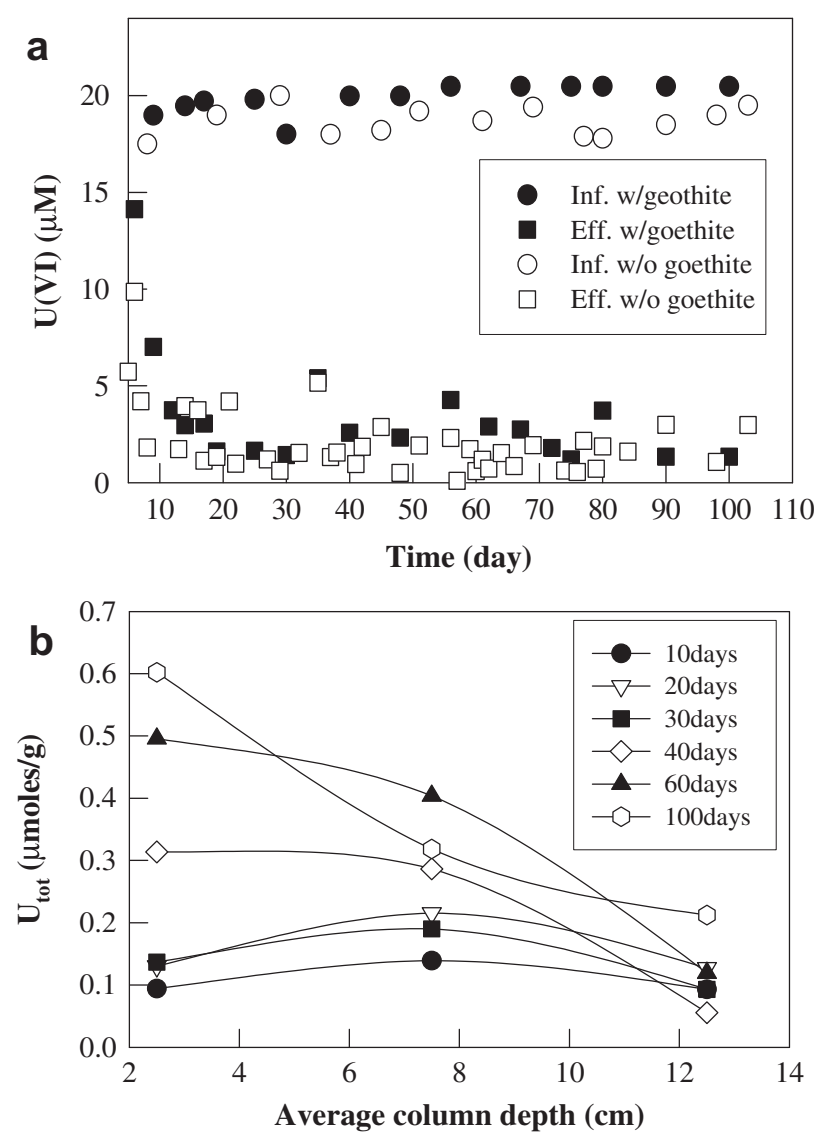

Fig. 1 - (a) Influent (open symbols) and effluent (closed symbols) uranium concentration during biostimulation with or without ${ }^{57} \mathrm{Fe}$-goethite and (b) total uranium concentration on sediment with ${ }^{57} \mathrm{Fe}$-goethite along the length of column during biostimulation. 

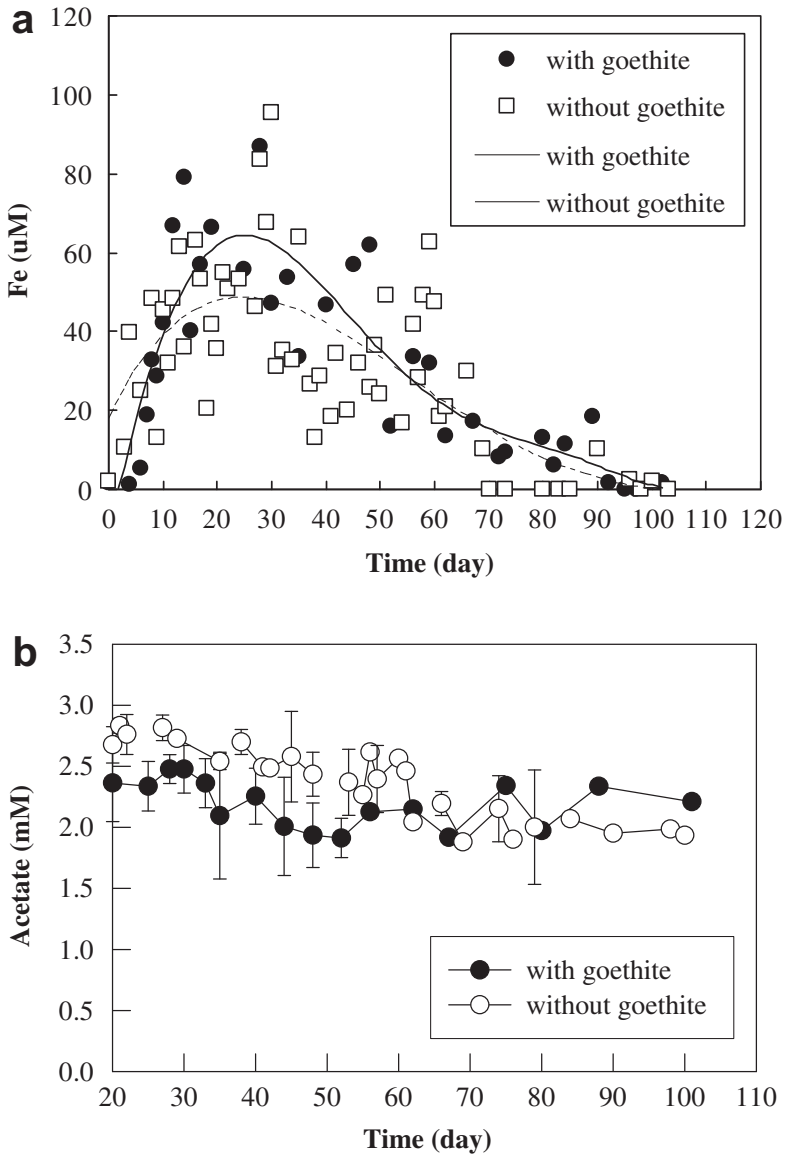

Fig. 2 - (a) Effluent Fe(II) and (b) acetate concentration in the columns with or without ${ }^{57} \mathrm{Fe}$-goethite.

Ethidium bromide and 100 ng of Halobacterium salinarium DNA were added to enhance visualization of the Old Rifle DNA bands after ultracentrifugation for $16 \mathrm{~h}$ at $80000 \mathrm{rpm}$ (227 $000 \mathrm{~g}$ ) in the Beckman Optima TL Ultracentrifuge 120.1 (Beckman Coulter, Fullerton, CA). The DNA was dialyzed on Millipore dialysis membrane filters (VSWP02500) for $45 \mathrm{~min}$ in $10 \mathrm{mM}$ Tris ( $\mathrm{pH}$ 8.2). After dialysis the DNA was stored at $-80^{\circ} \mathrm{C}$ until future analysis.

\section{PCR}

The bacterial community dynamics were assessed by TRFLP profiling of 16S rRNA genes amplified from genomic DNA $(<10 \mathrm{ng})$ in $50 \mu \mathrm{l}$ reactions using $20 \mathrm{pmol}$ universal primer $27 \mathrm{~F}$ (5'AGA GTT TGA TCC TGG CTC AG3') and non-labeled, bacterial-specific 1100 Reverse primer (5'GGG TTG CGC TCG TTG 3') per reaction. PCR amplification parameters were as follows, $94^{\circ} \mathrm{C}$ for $5 \mathrm{~min}$ then 25 cycles of $94^{\circ} \mathrm{C}$ for $30 \mathrm{~s}, 57^{\circ} \mathrm{C}$ for $30 \mathrm{~s}$ and $72{ }^{\circ} \mathrm{C}$ for $70 \mathrm{~s}$ with a final extension at $72{ }^{\circ} \mathrm{C}$ for $10 \mathrm{~min}$. Active microbes were determined by RT-PCR/TRFLP analysis of rRNA. Ribosomal RNA was isolated from the total nucleic acid preps after visualization on agarose gels of high molecular weight RNA with little degradation. The total nucleic acid sample was then diluted 1:100 and the Turbo DNA ${ }^{\mathrm{TM}}$ free kit (Applied Biosystems, Foster City, CA) was used to remove any DNA. The sample was diluted again to a final dilution of $10^{-4}$ before RT-PCR. Two $\mu$ l of this dilution was used as template for the Titan One Tube RT-PCR kit (Roche Diagnostics Corporation, Indianapolis, ID). Blank controls as well as PCR controls were run to assure no DNA contamination. No amplification was observed in any of the controls.

\subsection{Terminal restriction fragment length polymorphism analysis (TRFLP)}

Fluorescently labeled PCR product was run on a 1\% agarose gel and the product was quantified by image analysis. Fifteen ng of PCR product was digested with MnlI endonuclease (New England Biolab, Beverly, MA). All digests were in $20 \mu$ l volumes for $6 \mathrm{~h}$ at $37^{\circ} \mathrm{C}$. Precipitation of digested DNA was performed by adding $2 \mu \mathrm{l}$ of $0.75 \mathrm{M}$ sodium acetate solution and $0.4 \mu \mathrm{l}$ glycogen $(100 \mathrm{mg} / \mathrm{ml})$ with $37 \mu \mathrm{l}$ of $95 \%$ ethanol. The precipitated DNA was washed with $70 \%$ ethanol, dried, and re-suspended in $19.7 \mathrm{ml}$ de-ionized formamide with $0.3 \mu \mathrm{l}$ ROX 500 size standard (Applied Biosystems, Foster City, CA) for 15 minutes then denatured at $94{ }^{\circ} \mathrm{C}$ before analysis. TRFLP fingerprinting was carried out on a ABI 310 genetic analyzer (Applied Biosystems, Foster City, CA) using Genescan software. Peak detection was set at 25 arbitrary fluorescent units. For comparative analysis, all peaks (TRFs), within a profile were normalized to the total

Table 1 - The influent and effluent sulfate concentration during biostimulation in presence or absence of ${ }^{57}$ Fe-goethite.

Biostimulation time

\begin{tabular}{lllc}
\cline { 2 - 4 } time & $\begin{array}{c}\text { Influent } \\
(\mathrm{mM})^{\mathrm{b}}\end{array}$ & $\begin{array}{c}\text { Effluent } \\
(\mathrm{mM})^{\mathrm{b}}\end{array}$ & $\begin{array}{c}\text { Sulfate removal } \\
(\mathrm{mM})^{\mathrm{a}}\end{array}$ \\
\hline Day 10 & $9.26( \pm 0.17)^{\mathrm{b}}$ & $8.90 \pm(0.16)$ & $\underline{0.36}$ \\
Day 20 & $9.16( \pm 0.01)$ & $9.08 \pm(0.49)$ & $\underline{0.08}$ \\
Day 30 & $9.26( \pm 0.17)$ & $9.02 \pm(0.19)$ & $\underline{\underline{0.24}}$ \\
Day 40 & $10.38( \pm 0.15)$ & $9.24 \pm(0.56)$ & $\underline{1.14}$ \\
Day 60 & $10.46( \pm 0.20)$ & $9.05 \pm(0.67)$ & $\underline{1.41}$ \\
Day 80 & $10.38^{\mathrm{c}}$ & $8.99 \pm(0.43)$ & $\underline{1.39}$ \\
Day 100 & $9.63^{\mathrm{c}}$ & $8.50^{\mathrm{c}}$ & $\underline{1.13}$
\end{tabular}

Sediment without ${ }^{57} \mathrm{Fe}$-goethite

\begin{tabular}{rcc}
\hline $\begin{array}{c}\text { Influent } \\
(\mathrm{mM})^{\mathrm{d}}\end{array}$ & $\begin{array}{c}\text { Effluent } \\
(\mathrm{mM})^{\mathrm{d}}\end{array}$ & $\begin{array}{c}\text { Sulfate removal } \\
(\mathrm{mM})^{\mathrm{a}}\end{array}$ \\
9.09 & 8.53 & $\underline{0.56}$ \\
9.10 & 8.86 & $\underline{0.24}$ \\
9.04 & 8.35 & $\underline{\underline{0.69}}$ \\
10.46 & 9.98 & $\underline{0.48}$ \\
9.09 & 7.72 & $\underline{1.37}$ \\
9.09 & 7.60 & $\underline{1.49}$ \\
10.29 & 8.55 & $\underline{1.74}$
\end{tabular}

a Influent sulfate concentration-effluent sulfate concentration.

b Average ( \pm standard deviation) $n=7$, day $10 ; 6$, day 20; 5, day 30; 4, day 40; 3, day 80; 1, day 30; 1, day 100 .

c One data point was obtained.

d From one same column $31 \mathrm{HCO}_{3}^{-}+0.1155 \mathrm{HS}^{7-}+0.114 \mathrm{H}_{2} \mathrm{O}$. 
Table 2 - Acetate utilization in the two columns operated for 100 days. The change in acetate is the difference

between the influent and effluent acetate concentrations at each time point.

\begin{tabular}{rcc}
\hline & $\begin{array}{c}\Delta \text { Acetate Sediment } \\
\text { with } \begin{array}{c}57 \text { Fe-goethite } \\
(\mathrm{mM})\end{array}\end{array}$ & $\begin{array}{c}\Delta \text { Acetate Sediment } \\
\text { without } \\
(\mathrm{mM})\end{array}$ \\
\hline Day 10 & 0.61 & 0.64 \\
Day 20 & 0.71 & 0.42 \\
Day 30 & 0.48 & 1.50 \\
Day 40 & 1.29 & 0.71 \\
Day 60 & 1.07 & 1.02 \\
Day 80 & 1.02 & 1.49 \\
Day 100 & 1.12 & 1.27 \\
\hline
\end{tabular}

area for that sample and any peak $<0.5 \%$ of the total was excluded from the analysis. The similarity between any two samples was established based on presence or absence of TRFs using a Sorensen's index: $\mathrm{C}_{\mathrm{s}}=2 \mathrm{~N}_{\mathrm{ab}} /\left(\mathrm{N}_{\mathrm{a}}+\mathrm{N}_{\mathrm{b}}\right)$ where $\mathrm{N}_{\mathrm{ab}}$ is the number of shared TRFs and $\mathrm{N}_{\mathrm{a}}$ and $\mathrm{N}_{\mathrm{b}}$ are the number of TRFs detected in sample a and $b$ respectively. The comparative Sorensen index was calculated for all sample pairs of the normalized profiles using the COMbinatorial Polythetic Agglomerative Hierarchical clustering package (Berardesco et al., 1998). Duplicate extractions of some column sediment were performed to determine methodological variation.

Identification of the major TRFs was accomplished by creating and screening clonal libraries. The Topo TA cloning kit (Invitrogen, Carlsbad, CA) was used to create a library from the ${ }^{57} \mathrm{Fe}$-geothite amended and non-amended columns. A total of 120 clones were screened by PCR/TRFLP of the gene insert from the combined libraries. The clones that matched a desired TRF were sequenced with 27 Forward and 519 Reverse primers and the assembled sequence was compared to entries in the GenBank database.

\subsection{Quantitative polymerase chain reaction ( $Q-P C R)$ analysis}

DNA was extracted from sediment samples ( $0.5 \mathrm{~g}$ each) using the FastDNA spin kit for soil (BIO101, USA) and eluted in $100 \mu \mathrm{L}$ 1/10 TE buffer. All Q-PCR was performed by Microbial Insights Inc. (Rockford, TN). Each $30 \mu \mathrm{L}$ TaqMan based PCR assay contained DNA template, $1 \mathrm{X}$ TaqMan Universal PCR Master Mix (Applied Biosystems), TaqMan probe (100-500 nM) and forward and reverse primers (300-1500 nM). TaqMan assays were performed on an ABI Prism 7300 Sequence Detection System (Applied Biosystems) with the following temperature program: $2 \mathrm{~min}$ at $50{ }^{\circ} \mathrm{C}$ and $10 \mathrm{~min}$ at $95^{\circ} \mathrm{C}$, followed by 50 cycles of $15 \mathrm{~s}$ at $95^{\circ} \mathrm{C}$ and $1 \mathrm{~min}$ at $58^{\circ} \mathrm{C}$. The following groups of bacteria were targeted with the indicated TaqMan probe and forward/reverse primers, respectively: Eubacteria (TM1389, BACT1369/PROK1492R, (Suzuki et al., 2000)); Iron- and sulfate-reducing bacteria (GBC2, 361F/685R, (Stults et al., 2001)); Dissimilatory sulfite reductase gene (1F/ 5R), (Karr et al., 2005); and Geobacteraceae (GBC2, 561F/825R, (Stults et al., 2001)). Each $30 \mu \mathrm{L}$ SYBR green PCR assay contained DNA template, $1 \mathrm{X}$ clone PfuBuffer (Stratagene), $0.4 \mathrm{mM}$ $\mathrm{MgCl}_{2}, 0.2 \mathrm{mM}$ of each dNTP (Roche Applied Science), SYBR green (1:30 000 dilution, Molecular Probes), 1 U PfuTurbo HotStart DNA polymerase (Stratagene), DMSO (0-0.5 $\mu \mathrm{L})$, and forward and reverse primers (500-2500 nM). SYBR green assays were performed using an ABI Prism 7000 Sequence Detection System (Applied Biosystems) with temperature cycles varied based on primer set. Calibrations were obtained using a serial dilution of positive control DNA. The Sequence Detector program subtracted background signal for each sample during cycles 3 through 15 . The fluorescence threshold was computed as $10 \times$ the standard deviation of the background signal and the original concentration of DNA in each sample was determined by comparing the Ct sample values with the calibration data. Gene copy numbers were calculated assuming $9.13 \times 10^{14} \mathrm{bp} / \mu \mathrm{g}$ DNA.

\section{Results}

\subsection{Monitoring of chemical species during biostimulation}

U(VI) removal during biostimulation was observed in both sets of sediment columns (with and without ${ }^{57} \mathrm{Fe}$-goethite amendment). Upon commencement of the $3 \mathrm{mM}$ acetate addition, $\mathrm{U}$ (VI) concentrations decreased from 20 to $2-5 \mu \mathrm{M}$ within 20 days (Fig. 1(a)). For sediments with ${ }^{57} \mathrm{Fe}$-goethite amendment, uranium accumulated uniformly in the sediment along the length of the columns at the beginning of the biostimulation period ( 30 days), however for longer stimulation times most of the uranium was immobilized near the inflow (bottom) of

\begin{tabular}{|c|c|c|c|c|c|c|c|c|}
\hline & & Day 10 & Day 20 & Day 30 & Day 40 & Day 60 & Day 80 & Day 100 \\
\hline \multirow{4}{*}{$\begin{array}{l}\text { Sediment with }{ }^{57} \mathrm{Fe} \text {-goethite } \\
\text { amendment }\end{array}$} & $\mathrm{Fe}(\mathrm{II})(\mu \mathrm{mol} / \mathrm{g})$ & $28.1(6.6)^{\mathrm{a}}$ & $34.0(3.1)$ & $30.4(2.6)$ & $38.0(3.2)$ & $39.1(6.5)$ & $38.6(0.7)$ & $45.3(5.5)$ \\
\hline & Total Fe $(\mu \mathrm{mol} / \mathrm{g})$ & $53.6(4.9)$ & $53.0(2.7)$ & $46.1(0.5)$ & $52.9(5.9)$ & $51.0(6.6)$ & $46.5(1.4)$ & $49.9(4.5)$ \\
\hline & $\mathrm{Fe}(\mathrm{III})^{\mathrm{b}}(\mu \mathrm{mol} / \mathrm{g})$ & 25.5 & 19.0 & 15.7 & 14.9 & 11.9 & 7.9 & 4.6 \\
\hline & $\mathrm{Fe}(\mathrm{II}) / \mathrm{Total} \mathrm{Fe}$ & $0.52(0.07)$ & $0.64(0.09)$ & $0.66(0.05)$ & $0.72(0.14)$ & $0.76(0.03)$ & $0.83(0.01)$ & $0.91(0.06)$ \\
\hline \multirow{4}{*}{$\begin{array}{l}\text { Sediment without }{ }^{57} \mathrm{Fe} \text {-goethite } \\
\text { amendment }\end{array}$} & $\mathrm{Fe}(\mathrm{II})(\mu \mathrm{mol} / \mathrm{g})$ & $14.7(0.1)$ & 21.6 (1.58) & $15.5(4.11)$ & $18.1(1.4)$ & $30.8(2.5)$ & 38.5 (1.9) & $43.7(9.4)$ \\
\hline & Total Fe $(\mu \mathrm{mol} / \mathrm{g})$ & $33.4(0.0)$ & $41.0(6.2)$ & $36.6(4.8)$ & $35.4(1.5)$ & $36.4(3.8)$ & $42.2(2.5)$ & $45.1(6.0)$ \\
\hline & $\mathrm{Fe}(\mathrm{III})^{\mathrm{b}}(\mu \mathrm{mol} / \mathrm{g})$ & 18.7 & 19.4 & 21.1 & 17.3 & 5.6 & 3.7 & 1.4 \\
\hline & $\mathrm{Fe}(\mathrm{II}) /$ Total Fe & $0.44(0.00)$ & $0.54(0.10)$ & $0.44(0.11)$ & $0.51(0.05)$ & $0.86(0.19)$ & $0.94(0.10)$ & $0.96(0.09)$ \\
\hline
\end{tabular}

a average value (standard deviation, $n=9$ ).

b Determined from the difference between Fe (II) and total Fe $+0.0038 \mathrm{NH}_{4}^{+} \rightarrow 0.0038$ biomass $+0.231 \mathrm{HCO}_{3}^{-}+0.1155 \mathrm{HS}^{-}+0.114 \mathrm{H}_{2} \mathrm{O}$ 
Table 4 - Fe(II) partitioning as a function of time for the ${ }^{57}$ Fe-goethite amended sediments.

\begin{tabular}{|c|c|c|c|c|c|c|c|}
\hline Biostimulation time (days) & $\sim 10$ & $\sim 20$ & $\sim 30$ & $\sim 40$ & $\sim 60$ & $\sim 80$ & $\sim 100$ \\
\hline Cumulative $\mathrm{Fe}(\mathrm{II})$ in effluent $(\mu \mathrm{mol})$ & 8 & 28 & 73 & 93 & 154 & 132 & 141 \\
\hline Extracted $\mathrm{Fe}(\mathrm{II})$ from sediment $(\mu \mathrm{mol} / \mathrm{g})$ & 28 & 34 & 30 & 38 & 39 & 39 & 45 \\
\hline Extracted Fe(II) from sediment $(\mu \mathrm{mol})$ & 4200 & 5100 & 4500 & 5700 & 5850 & 5850 & 6750 \\
\hline Initial Fe(II) in sediment ( $\mu \mathrm{mol})$ & 1080 & 1080 & 1080 & 1080 & 1080 & 1080 & 1080 \\
\hline Reduced Fe(II) in sediment ( $\mu \mathrm{mol})$ & 3120 & 4020 & 3420 & 4620 & 4770 & 4770 & 5670 \\
\hline Total cumulative reduced Fe(II) & 3128 & 4048 & 3493 & 4713 & 4924 & 4902 & 5811 \\
\hline
\end{tabular}

the columns (Fig. 1(b)). An uranium mass balance for the sediment with ${ }^{57} \mathrm{Fe}$-goethite amendment for the 100 day biostimulation shown in Fig. 1(a) shows that $76.5 \mu \mathrm{mol}$ of uranium were removed based on the flow times the difference between the influent and effluent concentrations. The results from the extractions show that $56.5 \mu \mathrm{mol}$ of uranium was recovered from the sediment (Fig. 1(b)), which is in close agreement given the variability of uranium in the solid phase and that the solidphase estimates were done based on three homogenized samples. The same trend of uranium concentration in the sediment was observed in the column without ${ }^{57} \mathrm{Fe}$-goethite amendment sediments (data not shown).

Aqueous Fe(II) production occurred simultaneously with uranium removal. In both sediments, effluent Fe(II) concentrations ranged from 40 to $100 \mu \mathrm{M}$ prior to day 30 (Fig. 2a). At higher time points, however, their concentration was significantly lower due to biogenic Fe(II) mineral precipitation. Approximately 14\% more sulfate removal was observed in the columns without ${ }^{57} \mathrm{Fe}$-goethite amendment over the duration of the experiment (Table 1), which is consistent with a higher utilization of acetate in these columns as compared to columns with ${ }^{57} \mathrm{Fe}$-goethite amendment prior to day 60 (Fig. 2 (b) and Table 2). There was also a significant increase in sulfate utilization for both treatments for $t>40$ days of biostimulation compared to the sulfate utilization for $t<40$ days.

The $0.5 \mathrm{~N} \mathrm{HCl}$ extractable $\mathrm{Fe}(\mathrm{II})$ from the sediments increased over time throughout the biostimulation period (Table 3). Fe(II) in the sediment of the columns with ${ }^{57} \mathrm{Fe}-$ goethite addition was significantly larger during the first 60 days of biostimulation than in the non-amended columns (based on a t-test for each time point at a $5 \%$ confidence level). For biostimulation times larger than 60 days, Fe(II) in the sediments was no longer affected by the treatments. The ratio of Fe(II)/total Fe increased over time during the biostimulation period, and for both treatments most of the $0.5 \mathrm{~N} \mathrm{HCl}$ extractable Fe was Fe(II) by day 100. Table 4 shows cumulative Fe(II) levels as a function of time for the effluent and within the columns for ${ }^{57} \mathrm{Fe}$-goethite amendment sediment. Reduced clays and siderite as noted in our earlier studies with biostimulated/bioreduced Oak Ridge (TN) Field Research Center (FRC) and Old Rifle sediments (Kukkadapu et al., 2006; Komlos et al., 2008c) and biogenic green rust (GR) and magnetites in reduced Fe-oxide systems (Kukkadapu et al., 2004), are readily soluble in acid. Throughout the experiment, column backpressure increased from 1 psi (background pressure) to 7 psi due to biomass buildup and biogenic phases that precipitated (data not shown), the effluent $\mathrm{pH}$ remained at $8.63( \pm 0.26)$ [a condition favorably for precipitation of GR and magnetite], and dissolved oxygen was never detected in the column effluent.

Total acetate consumption is compared in Table 5 to the theoretical acetate consumption for direct iron and sulfate reduction in terms of total iron and sulfate reduced throughout the experiment. Results show that significantly less acetate was consumed than what one would expect based on the stoichiometry of the reduction of $\mathrm{FeOOH}_{(\mathrm{s})}$ and sulfate with acetate as the sole electron donor (see Table 5). The discrepancy between theoretical and observed acetate removal could result from carbon cycling between bacteria within the column. Based on the equations shown in Table 5 a fraction of the acetate is used to produce biomass and this carbon is not reutilized. If the organic carbon from the new biomass becomes available as additional electron donor due to carbon turnover, less acetate is needed as electron donor. Evidence of carbon cross-feeding between different denitrifying populations has been observed within 14 day when

Table 5 - Acetate utilization mass balance.

\begin{tabular}{|c|c|c|c|c|c|c|c|}
\hline & & $\begin{array}{l}\mathrm{Fe}(\mathrm{II}) \\
\text { produced } \\
(\mu \mathrm{mol})\end{array}$ & $\begin{array}{l}\text { Theoretical acetate } \\
\text { consumption for Fe } \\
\text { reduction }(\mu \mathrm{mol})^{\mathrm{a}}\end{array}$ & $\begin{array}{l}\text { Sulfate } \\
\text { removed } \\
(\mu \mathrm{mol})\end{array}$ & $\begin{array}{l}\text { Theoretical acetate } \\
\text { consumption for sulfate } \\
\text { reduction }(\mu \mathrm{mol})^{\mathrm{b}}\end{array}$ & $\begin{array}{c}\text { Observed } \\
\text { acetate } \\
\text { consumption } \\
(\mu \mathrm{mol})\end{array}$ & $\begin{array}{l}\text { Theoretical } \\
\text { acetate } \\
\text { consumption } \\
(\mathrm{a}+\mathrm{b})(\mu \mathrm{mol})\end{array}$ \\
\hline \multirow{2}{*}{$\begin{array}{l}\text { Sediment with } \\
{ }^{57} \mathrm{Fe} \text {-goethite }\end{array}$} & Day 0-30 & 3493 & 728 & 713 & 771 & 786 & 1484 \\
\hline & Day 30-100 & 2318 & 483 & 3767 & 4076 & 3301 & 4250 \\
\hline \multirow{2}{*}{$\begin{array}{l}\text { Sediment without } \\
{ }^{57} \mathrm{Fe} \text {-goethite }\end{array}$} & Day 0-30 & 1307 & 273 & 539 & 583 & 585 & 858 \\
\hline & Day 30-100 & 4308 & 898 & 4259 & 4609 & 3757 & 5507 \\
\hline \multicolumn{8}{|c|}{$\begin{array}{l}\text { Calculations were based on the following stoichiometry (Yabusaki et al., 2007). } \\
\text { a } 0.125 \mathrm{CH}_{3} \mathrm{COO}^{-}+0.6 \mathrm{FeOOH}(\mathrm{s})+1.155 \mathrm{H}^{+}+0.02 \mathrm{NH}_{4}^{+} \rightarrow 0.02 \mathrm{C}_{5} \mathrm{H}_{7} \mathrm{O}_{2} \mathrm{~N}+0.6 \mathrm{Fe}^{2+}+0.96 \mathrm{H}_{2} \mathrm{O}+0.15 \mathrm{HCO}_{3}^{-} \text {. } \\
\text { b } 0.125 \mathrm{CH}_{3} \mathrm{COO}^{-}+0.1155 \mathrm{SO}_{4}^{2-}+0.0057 \mathrm{H}^{+}+0.0038 \mathrm{NH}_{4}^{+} \rightarrow 0.0038 \mathrm{C}_{5} \mathrm{H}_{7} \mathrm{O}_{2} \mathrm{~N}+0.231 \mathrm{HCO}_{3}^{-}+0.1155 \mathrm{HS}^{-}+0.114 \mathrm{H}_{2} \mathrm{O} \\
\text { Where } \mathrm{C}_{5} \mathrm{H}_{7} \mathrm{O}_{2} \mathrm{~N} \text { represents biomass. }\end{array}$} \\
\hline
\end{tabular}



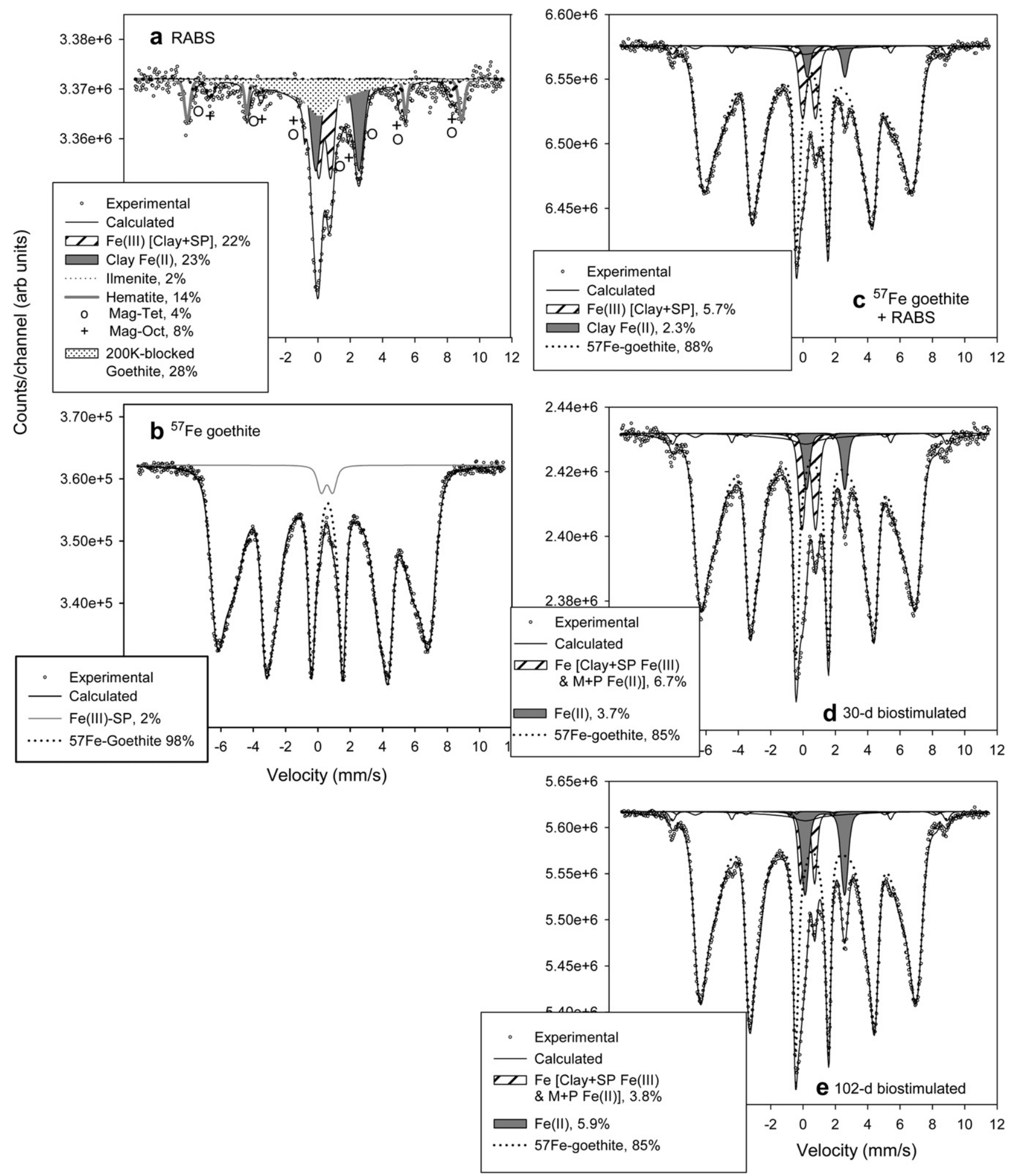

Fig. 3 - $200 \mathrm{~K}$ Mössbauer spectra of Rifle Aquifer Background Sediment (RABS) and unbiostimulated and biostimulated ${ }^{57}$ Fe-goethite amended RABS sediments. (a) RABS showing presence of clay Fe (II and III) and various Fe-oxides (legend: SP = superparamagnetic, Mag = magnetite, Tet $=$ tetrahedral, and Oct $=$ octahedral), (b) ${ }^{57}$ Fe-goethite, (c) RABS amended with ${ }^{57} \mathrm{Fe}$-goethite showing major contribution due to ${ }^{57} \mathrm{Fe}$-goethite, (d-e) biostimulated to various extents showing changes in ${ }^{57} \mathrm{Fe}$-oxide, Fe(II), and central Fe doublet (between 0 and $2 \mathrm{~mm} / \mathrm{s}$; clay and SP Fe(III), $\mathrm{M}=$ mackinawite and $\mathbf{P}=$ pyrite). In figures (c) to (e) contribution due to native minerals is not included in the labeled boxes to avoid cluttering. 
microcosms have been amended with benzoate (Gallagher et al., 2005). It is also possible that some Fe(III) was reduced abiotically by sulfide resulting in the production of elemental sulfur. It was shown that under $\mathrm{pH}$ conditions similar to the Rifle groundwater (Poulton, 2003; Poulton et al., 2004), a variety of Fe-oxides that exist in Rifle sediments, such as ferrihydrite, goethite, lepidocrocite, hematite, are reactive with sulfide. Under these conditions, the reduction of Fe-oxides to aqueous $\mathrm{Fe}(\mathrm{II})$ is coupled to oxidation of sulfide to elemental S. Presence of $\mathrm{S}$ under biostimulated conditions was readily evident in field samples that are biostimulated to deep sulfate-reducing conditions (unpublished results). Either or both processes could explain, at least in part, the lower acetate consumption than what was expected based on the stoichiometric equations given in Table 5. Finally, although unambigious presence of green rust with interlayer sulfate was not evident, as discussed below, its possible formation in these experiments could also explain the lower acetate utilization than what one would expect from these stoichiometric equations.

\subsection{Bioavailability and biotransformation of $\mathrm{Fe}$ - minerals}

The amount of $\mathrm{Fe}(0.12-0.15 \mathrm{wt} \%)$ amended as ${ }^{57} \mathrm{Fe}$-goethite to the sediments was $\sim 20$ times lower than the total Fe (natural) present in the system $\sim 3 \mathrm{wt} \%$ (Komlos et al., 2008c). Nevertheless this amount is sufficiently higher than the intrinsic ${ }^{57} \mathrm{Fe}$ content of the sediment $(0.05-0.06 \mathrm{wt} \% ; 2.2 \%$ [natural abundance of ${ }^{57} \mathrm{Fe}$ ] of the total $\mathrm{Fe}$ ), which would allow tracking of even minor transformations of the spiked ${ }^{57} \mathrm{Fe}$-goethite by the ${ }^{57} \mathrm{Fe}$ isotopic specific ${ }^{57} \mathrm{Fe}$-Mössbauer spectroscopy. The overall effect of addition of ${ }^{57} \mathrm{Fe}$-goethite on spectral features is evident from comparison of Fig. $3 \mathrm{a}-\mathrm{C} ;{ }^{57} \mathrm{Fe}$-goethite contribution to the amended spectrum is $88 \%$ (Fig. 3c). Changes in amended ${ }^{57} \mathrm{Fe}$-goethite upon biostimulation were particularly evident from Fig. 3 (modeled spectra) and a qualitative comparison (Fig. 4). The changes in native Fe-oxides (hematite, magnetite, and Al-goethite) (Fig. 3(a)) content upon biostimulation as evident in an earlier study (Komlos et al., 2008c), where loss of goethite (and clay reduction) was noted, were not modeled because of overwhelming interference of their peaks with the amended ${ }^{57} \mathrm{Fe}$-goethite sextet signature. For modeling purposes their parameters were therefore fixed as in the unamended sample. The modeling unambiguously demonstrated gradual increase in the $\mathrm{Fe}(\mathrm{II})$ doublet content with time; the increase from $2.3 \%(t=0$; Fig. 3c) to $5.9 \%$ ( $t=102$-d; Fig. 3e) although appears small is rather significant if the increase is mainly due to changes in native Fe-minerals (not due to spiked ${ }^{57} \mathrm{Fe}$-goethite).

Increase in the $\mathrm{Fe}$ (II) doublet content was mainly due to partial reduction of clay $\mathrm{Fe}(\mathrm{III})$. Most of the biogenic $\mathrm{Fe}(\mathrm{II})$ in the bioreduced/biostimulated sediments (e.g., DOE's Rifle and FRC sites; (Komlos et al., 2008c; Mohanty et al., 2008) was due to clay Fe(III) reduction; clay Fe(III) reduction was also noted in several pure clay systems (Dong et al., 2003). The increase in Fe (II) content may also be due to precipitation of siderite [Fe(II) $\left.\mathrm{CO}_{3}\right]$, and green rust $[\mathrm{Fe}(\mathrm{II}) / \mathrm{Fe}$ (III)-hydroxy carbonate/sulfate mineral (GR)], that may have mostly precipitated from Fe(II) (and $\mathrm{Fe}(\mathrm{III})$ ) coming from the reductive dissolution of native $\mathrm{Fe}$ (III)-oxides; $\mathrm{Fe}(\mathrm{II})$ (and $\mathrm{Fe}(\mathrm{III})$ ) doublet intensities would be
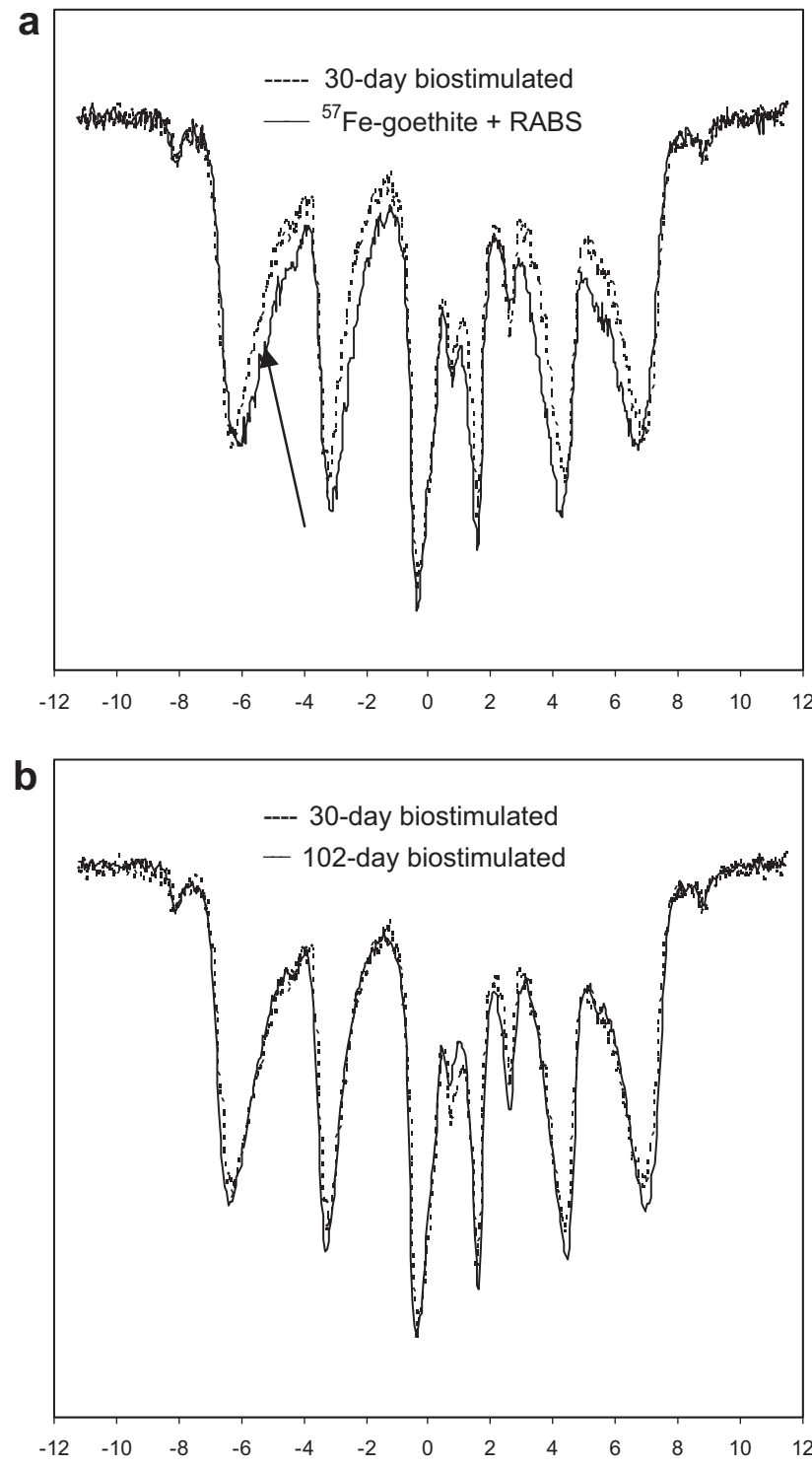

Fig. 4 - Unmodeled Mössbauer spectra of unbiostimulated and 30- and 102-d biostimulated samples showing (a) loss of a fraction of ${ }^{57} \mathrm{Fe}$-goethite upon biostimulation (30-d), arrow points to difference in goethite contents, and (b) similar ${ }^{57} \mathrm{Fe}-$ goethite contents in $30-\mathrm{d}$ and $102-$ d biostimulated samples.

significantly higher if they were derived from ${ }^{57} \mathrm{Fe}$-goethite. Fe (II) peak contributions from siderite and GR, which exhibit somewhat different parameters than clay Fe(II) (and Fe(III)), however were not modeled into individual phases because of ${ }^{57} \mathrm{Fe}$-goethite interference. Mössbauer and Fe-XAS methods unambiguously have shown the presence of siderite in field biostimulated Rifle sediments (unpublished). Siderite is also the major biogenic product of sediments containing Algoethite (Kukkadapu et al., 2001). Green rust (most probably due to sulfate) and magnetite are also a possibility based on presence of both Fe(II) and Fe(III) in acid extractants (Table 3). However, like GR, magnetite peaks (if any derived from native Fe-oxide transformation) would be overwhelmed by 
${ }^{57} \mathrm{Fe}$-goethite. The unbiostimulated and biostimulated spectra would be significantly different if the magnetite is derived from ${ }^{57} \mathrm{Fe}$-goethite.

Columns turned black upon biostimulation, suggesting precipitation of iron sulfides (mackinawite, greigite, and pyrite). Secondary mineral precipitates with Fe and S atomic composition similar to mackinawite, greigite, and pyrite were evident from SEM-EDX measurements (a mineral precipitate with atomic composition similar to greigite is shown in Fig. 5 as an example). Mackinawite and pyrite Fe(II) contributions (low spin Fe(II) vs. high spin Fe(II) as in clay and siderite), however, were not apparent because their peak positions overlap with clay Fe(III) (Fig. 3) (Murad and Cashion, 2004). Similarly greigite peaks are not evident in Mössbauer spectra, because of interference from ${ }^{57} \mathrm{Fe}$-goethite.

The ${ }^{57} \mathrm{Fe}$-goethite appears to be not very reactive under our biostimulated conditions. The decrease in ${ }^{57} \mathrm{Fe}$-goethite noted during the first 30-days (Fig. 4a) is due to reduction of relatively more bioavailable small-particle or poorly-crystalline fraction of the sample. ${ }^{57} \mathrm{Fe}$-goethite remained more or less constant past 30 -days. The noted decrease in ${ }^{57} \mathrm{Fe}$-goethite content upon biostimulation, from $88 \%$ in the $t=0$ sample, to $85 \%$ in both the 30 -day and 102-day samples, implies that it is probably not the major source of the eluted Fe(II), Fe-sulfide minerals, nor other Fe(II)/Fe(III) phases (as discussed in earlier sections). The central doublet peak would be significantly higher if ${ }^{57} \mathrm{Fe}$-sulfides were precipitated. Also the decrease in ${ }^{57} \mathrm{Fe}$ (II) content was significantly lower than the eluted Fe(II).

\subsection{Microbial community characterization}

4.3.1. Total microbial community dynamic

TRFLP analysis was conducted to monitor total microbial community changes within the column during the biostimulation period. In all there were 96 different TRFs detected in the 27 profiles analyzed. Of the TRFLP peaks detected, 4 TRFs were found in all of the samples $(208,213,277$ and $292 \mathrm{bp})$ while 23 TRFs (24\%) were present in only one sample. Most profiles of the sediment-attached microbial communities were dominated by 9 TRFs. Five of these peaks (187, 206, 210, 213 and $292 \mathrm{bp}$ ) were closely related to Geobacter-like species based on sequence analysis of clones $16 \mathrm{~S}$ rRNA genes. The Geobacter-like group comprised $25-57 \%$ of the total profile area throughout the experiment (see Fig. 6). TRF 213 (closest match by NCBI blast as a Geobacter-like clone collected at the Rifle field site (Holmes et al., 2007)), was the most dominant peak in the sediments. This particular microorganism seems to have established itself early in the columns after being below the detection limit in the initial sediment. Two additional TRFs (235 bp; Dechloromonaslike and 208 bp; Rhodoferax-like) accounted for $0-16 \%$ and $5-30 \%$ respectively of the overall profile area. Some other TRFs were found to comprise $5-21 \%$ of the profiles but remain uncharacterized (277 and $289 \mathrm{bp}$ ). Other peaks were more prevalent in the column without ${ }^{57} \mathrm{Fe}$-goethite (176 and $186 \mathrm{bp}$ ). While a 71 bp peak was associated with the ${ }^{57} \mathrm{Fe}$-Geothite column more than the unamended sediments.

The initial old Rifle site sediment had considerably more richness and diversity (Shannon index: 3.2) compared to the biostimulated sediment (Shannon index: 2.0-2.6). There was an average of 39 TRFs in the initial sediment sample TRFLP a

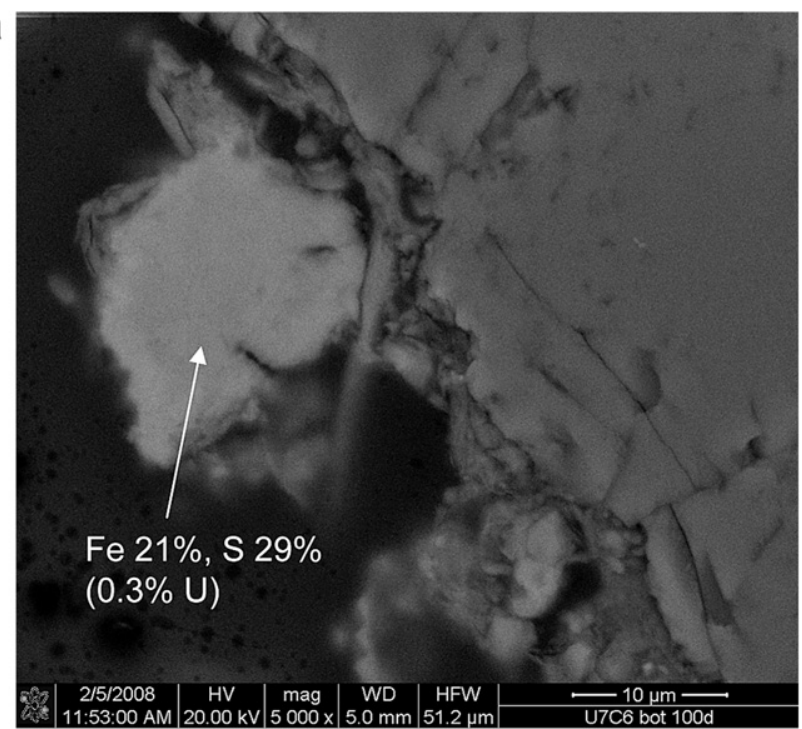

b

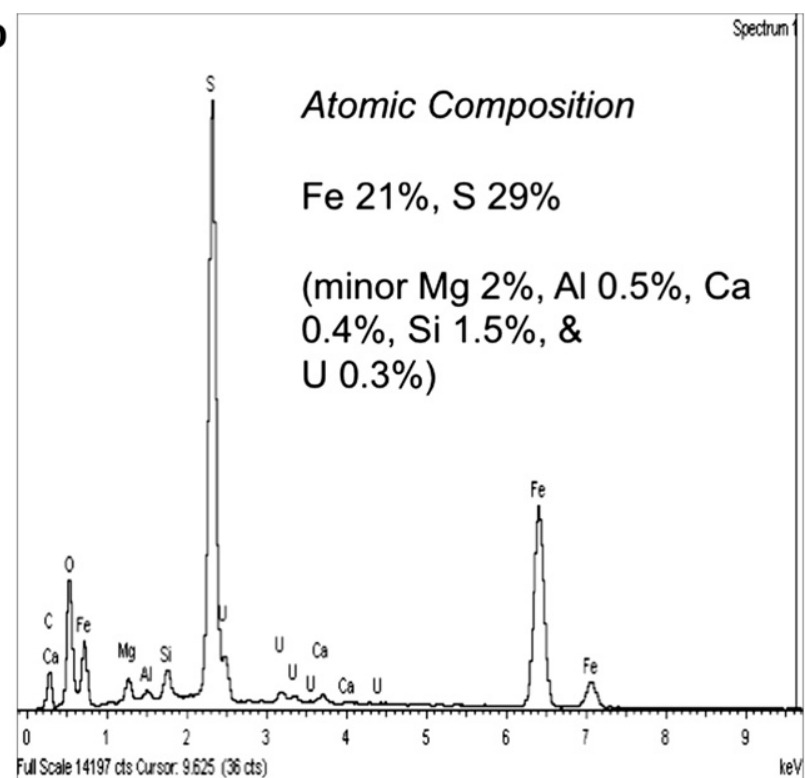

Fig. 5 - Backscattered SEM image of a polished sample (102-d biostimulated; bottom third of column near inflow) showing (a) Fe-S precipitate with (b) EDX-derived Fe and S atomic composition similar to greigite $\left(\mathrm{Fe}_{3} \mathrm{~S}_{4}\right)$, with associated $U$ (arrow indicates the location of EDX sampling).

fingerprints as compared to that of the sediment by day 10 with an average of 20 TRFs. Similarity Indices of the sediment from the initial sample to that of day 10 were on the range of $0.39-0.48$ signifying that less than $1 / 2$ of the initial population was still detectable after 10 days of acetate addition.

\subsubsection{Iron-reducing bacteria}

There were 10 Geobacter-like species detected in the column sediments at the DNA level. These included the 5 prevalent peaks discussed earlier. After 10 days of biostimulating the sediment amended with ${ }^{57} \mathrm{Fe}$-goethite, the identified Geobacter-like species accounted for an average of $48 \%$ of the total 

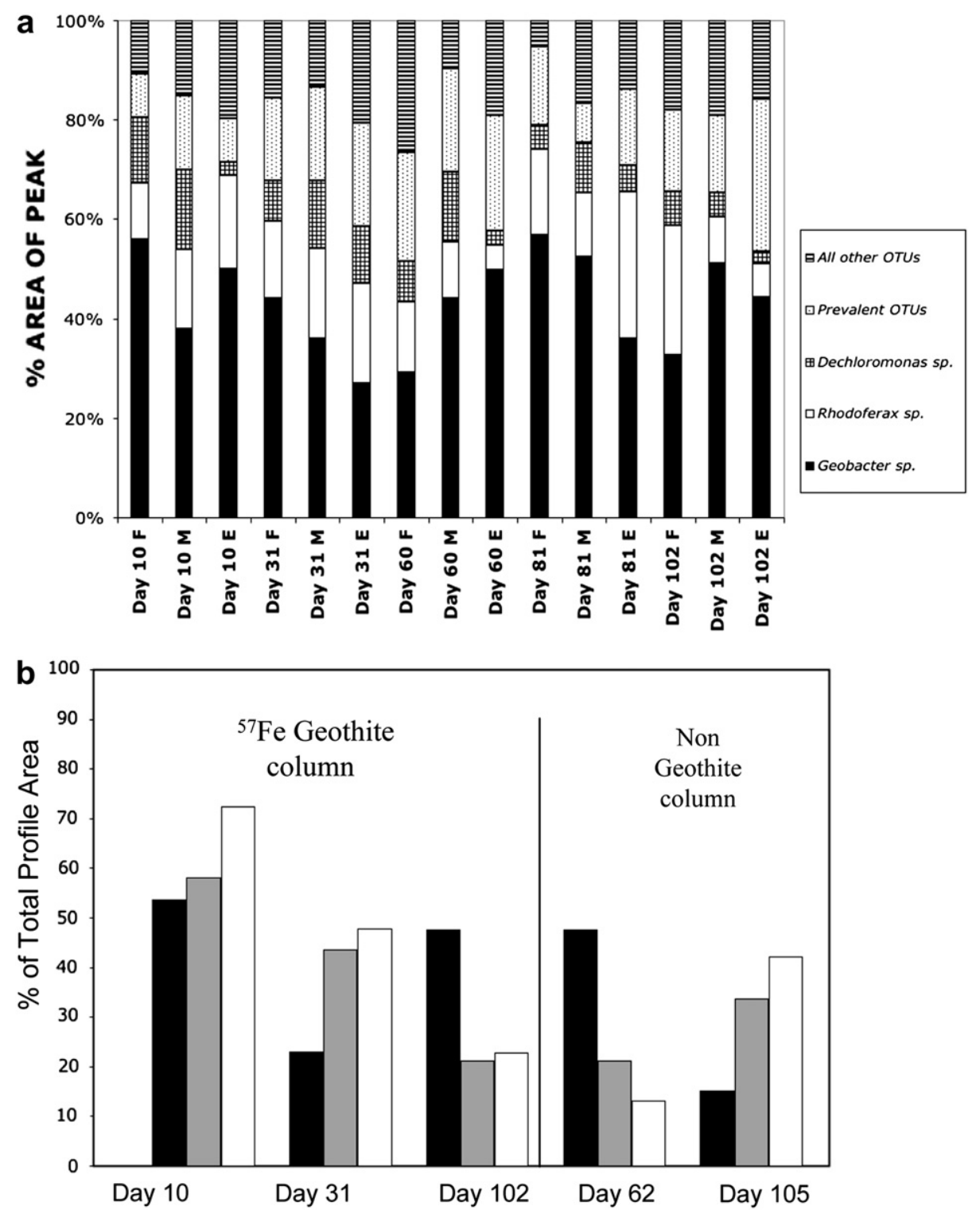

Fig. 6 - (a); Dominant peaks in Fe57 Geothite amended column based on DNA analysis. (b) Geobacter-like activity based on ribosomal RNA analysis of the geothite amended and non-amended columns Beginning, Middle, End of Column, black, grey and white respectively

microbial profile in the sediment and slightly decreased to $35 \%$ by day 30 . They remained the major component among the microbial community identified throughout the biostimulation period (Fig. 6a). Most of the bacteria, including Geobacter-like species, were actively synthesizing ribosomes and replicating throughout the biostimulation time, including during sulfate reduction (Fig. 6(b)). TRF 213 (a Geobacter-like species) was much more active at day 102 near the inflow of the column relative to the outflow of the column, which coincides with the higher level of precipitated uranium near the inflow during the second half of the experiment.

In the sediment without ${ }^{57} \mathrm{Fe}$-goethite, the identified Geobacter-like species accounted for 32 to $44 \%$ of total population in the sediment at the DNA level. The community profiles for the non-geothite columns were highly similar to the ${ }^{57} \mathrm{Fe}$-goethite column seen in Fig. $6 \mathrm{a}$ and the data is not presented. However, the activity (as measured by the relative proportion of the ribosome profile) from the Geobacter-like species was generally less than that of the ${ }^{57} \mathrm{Fe}$-goethite amended sediment (Fig. 6b), especially during the first 30 days of biostimulation, when much more iron was reduced in the ${ }^{57} \mathrm{Fe}$-goethite amended sediment. These finding indicate that Geobacter-like activity persists during the sulfate-reducing phase in both column experiments and that goethite amendment can enhance the activity of the iron-reducers during the biostimulation period.

The qPCR data show the presence of Geobacter sp. throughout the duration of the experiment, with cell numbers dropping by over an order of magnitude from the first 20 days of biostimulation to day 100 of the biostimulation period (Fig. 7). For longer times ( $t>60$ days), when sulfate reduction was the dominant TEAP, the biomass of Geobacter sp. in the sediments decreased gradually (Fig. 7). 
After 30 days of biostimulation, the difference between iron-reducing bacteria/sulfate-reducing bacteria and Geobacter sp. increased over time, which means that when sulfate reduction becomes dominant, the biomass of sulfate-reducing bacteria increased with time relatively to that of Geobacter sp or that other iron-reducers besides Geobacter became a significant part of the microbial community.

\subsubsection{Sulfate-reducing bacteria}

The qPCR data showed only minor differences in biomass trends for iron-reducing bacteria/sulfate-reducing bacteria and Goebacter sp. between the sediments with and without ${ }^{57} \mathrm{Fe}$-goethite amendment. However, after sulfate reduction became the dominant TEAP, the sulfite reductase gene (dsr) in the sediments without ${ }^{57} \mathrm{Fe}$-goethite amendment was about an order of magnitude higher than in the sediments with the ${ }^{57} \mathrm{Fe}$-goethite (Fig. 7), which is in agreement with the increased sulfate and acetate removal observed for these columns.

\subsection{4. (iv) overall impact of ${ }^{57} \mathrm{Fe}$-goethite amendment on} microbial community

In order to ascertain if goethite amendment could significantly shift the entire Rifle microbial community in a different direction, a cluster analysis was performed based on Sorensen's similarity indices from the various profiles of both the
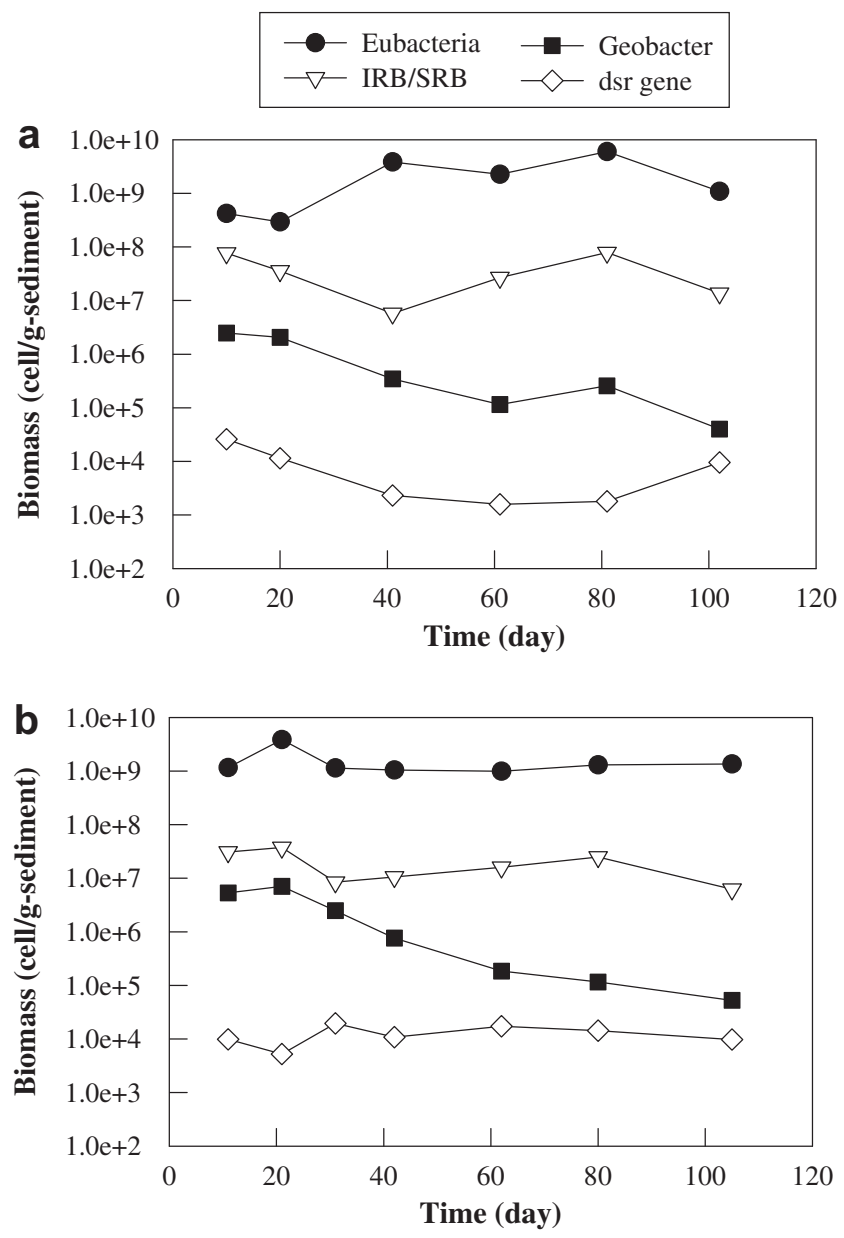

Fig. 7 - qPCR community structure throughout the biostimulation (a) with or (b) without ${ }^{57} \mathrm{Fe}$-goethite.
${ }^{57} \mathrm{Fe}$ and the non-amended sample sets (Fig. 8). This approach indicates which samples, are most closely related to each other in a graphical format, and typically demonstrates temporal clustering of replicates from bioreactors as conditions change during operation (McGuinness et al., 2006). In this study, the clustering demonstrated a distinct separation between communities in the ${ }^{57} \mathrm{Fe}$-geothite amended and the non-amended control. Specifically, all ${ }^{57} \mathrm{Fe}$ goethite amended profiles clustered separately from all non-amended controls at all time points. The Sorensen's similarity indices ranged from 0.96 to 0.56 during the course of the experiment with the average within-column similarity index higher at earlier time points, but declining over time. For example, the community in the ${ }^{57} \mathrm{Fe}$-goethite columns at day 10 and 31, had similarity indices of 0.83 and 0.85 respectively. However, by day 102 the average index was 0.69 , while the non-amended columns had a lower average index of 0.74 on day 21, which declined to 0.63 by day 105 . This decline indicated that both communities within the top, middle, and bottom thirds of the columns were differentiating spatially over time. There was a clear separation of the two treatment types except for the final days of the experiment where the variability within each column was equal to the differences between the two treatments.

\section{Discussion}

In this study, columns packed with background sediment from the Old Rifle site (with and without the addition of small amounts of small-particle ${ }^{57} \mathrm{Fe}$-goethite) were biostimulated via $3 \mathrm{mM}$ acetate addition for over 100 days to simulate a U(VI) bioremediation scenario. Iron reduction and sulfate as well as $\mathrm{U}(\mathrm{VI})$ removal was observed shortly after acetate was added to the influent, and was followed by an increase in sulfate removal at about 30-40 days later. Uranium removal continued throughout the experiment, which suggested that the decrease of iron reduction and increase of sulfate removal did not affect uranium reduction in either treatment (i.e., with or without ${ }^{57} \mathrm{Fe}$-goethite). This result differs from the field experimental observations by (Anderson et al., 2003) who, for the same acetate and sulfate concentrations, observed that $U$ (VI) removal efficiency decreased with concurrent decrease in groundwater sulfate contents. It was hypothesized that the decrease in $\mathrm{U}(\mathrm{VI})$ removal efficiency was due to a loss in the metal-reducing population (i.e., Geobacter) resulting from a depletion of the bioavailable Fe(III) concentration when sulfate reduction became the dominant TEAP. However, results presented here show that a shift to sulfate reduction as the dominant TEAP during biostimulation is not due to complete depletion of bioavailable $\mathrm{Fe}$ (III) (both with and without ${ }^{57} \mathrm{Fe}$-amendment), but is likely related to the gradual utilization of the more bioavailable (i.e. amorphous) Fe(III), and that Geobacter-like microbes remained active after the sulfate reduction became the dominant TEAP and throughout the 100-day biostimulation period.

The addition of the ${ }^{57} \mathrm{Fe}$-goethite to the sediment had a noticeable effect on the overall composition of the microbial population (Fig. 8). A greater portion of Geobacter sp. in the microbial structure was observed in the sediment with ${ }^{57} \mathrm{Fe}-$ goethite as compared to the non-goethite amended sediment. 


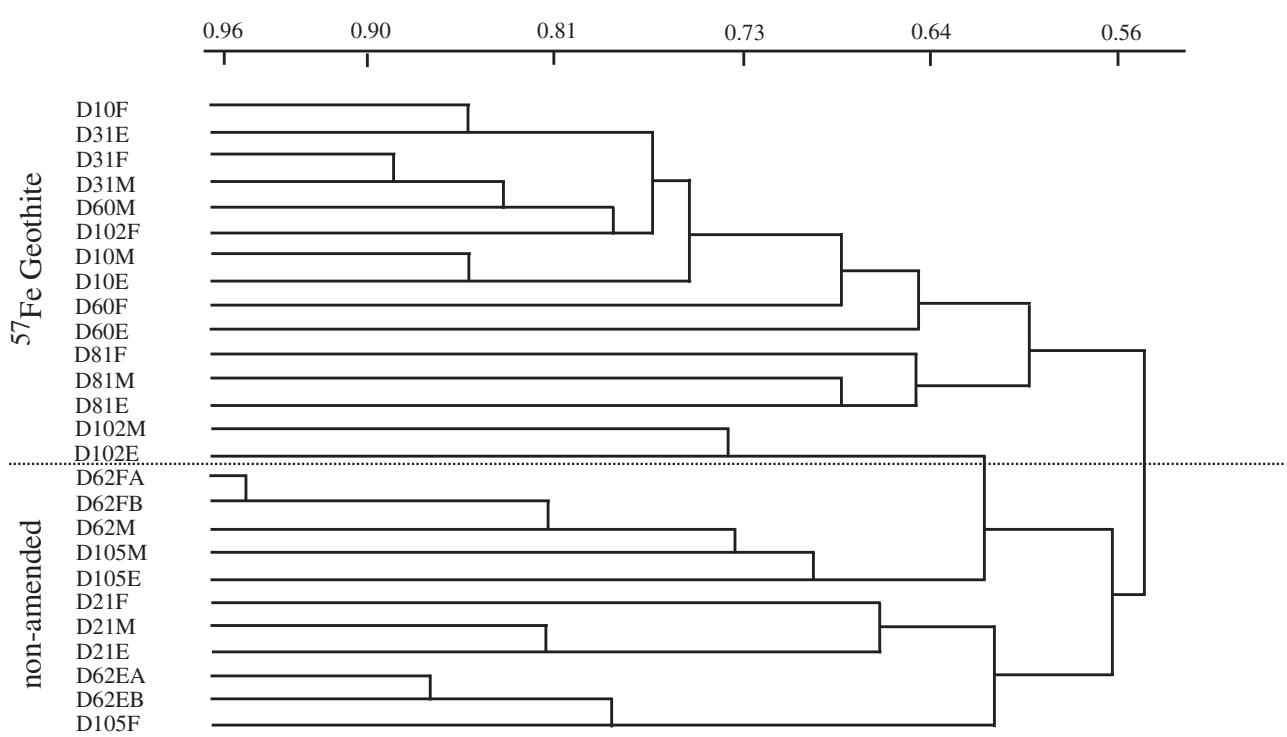

Fig. 8 - The Sorensen's comparison of the columns with (U7 series) or without ${ }^{57}$ Fe-goethite (U8 series).

The addition of ${ }^{57} \mathrm{Fe}$-goethite slightly suppressed the amount of sulfate reduced and hence also the acetate consumption, and it increased the overall iron reducing activity during the first 30 days of biostimulation. Previous studies have shown that, when bioavailable Fe(III) oxides are present, Fe(III)-reducing microorganisms can inhibit sulfate reduction by outcompeting sulfate reducers (Chapelle and Lovley, 1992; Lovley and Phillips, 1987a; Mohanty et al., 2008). Under the biostimulation conditions of the experiments described here, where iron-reducers never consumed all the acetate that was provided, increased Fe(III) via the addition of ${ }^{57} \mathrm{Fe}$-goethite resulted in lower numbers of sulfate reducers, but not in the inhibition of sulfate reduction. In all cases acetate in the column effluent was at least $1.5 \mathrm{mM}$, hence acetate was not limiting either TEAP. Overall, results showed that the addition of a bioavailable $\mathrm{Fe}(\mathrm{III})$ phase resulted in an increased electron flux towards iron reduction, as explained by Postma and Jakobsen (1996), while this phase was being reduced.

Over the 100-day biostimulation period, about $5821 \mu \mathrm{mol}$ of $\mathrm{Fe}(\mathrm{III})$ were reduced in the ${ }^{57} \mathrm{Fe}$-goethite amended sediments, while $5615 \mu \mathrm{mol}$ of $\mathrm{Fe}(\mathrm{III})$ were reduced in the non-amended sediment (Fig. 5). Only about $106 \mu \mathrm{mol}$ of Fe(III) from the ${ }^{57} \mathrm{Fe}$ goethite were reduced and only during the first 30 days of biostimulation (based on the initial composition and results shown in Fig. 3). Although total iron reduction between columns was similar over the 100-day period, iron reduction in the columns with the ${ }^{57} \mathrm{Fe}$-goethite was significantly stronger during the first 30 days $(3493 \mu \mathrm{mol}$ of Fe(III) for the amended vs. $1307 \mu \mathrm{mol}$ of Fe(III) for the non-amended sediments, see Table 5), which corresponds with the higher portion of Geobacter sp. in the microbial structure. It is likely that the bioavailable fraction of the ${ }^{57} \mathrm{Fe}$-goethite allowed for a faster growth of Geobacter sp. at the initial biostimulation phase, which then resulted in a faster reduction of all bioavailable Fe(III) phases. The same effect on increased bulk Fe(III) reduction due to the addition of nanosized iron oxide colloids was also reported by (Bosch et al., 2009). It is interesting that the earlier depletion of Fe(III) phases did not translate into a stronger sulfate reduced during the second phase (days 30-100), indicating that the relative importance between iron and sulfate reduction in a dynamic system, at least over a limited time span ( 100 days as shown here) is not only governed by the thermodynamics of the TEAPs, but also by the microbial interactions and their antecedent dynamics.

Since U(VI) was removed very effectively under both treatments, results show that $\mathrm{U}(\mathrm{VI})$ removal rate is not sensitive to the shifts in microbial dynamics and TEAPs observed in this study.

\section{Conclusions}

The goal of this research was to gain new insights on the microbial dynamics during the biostimulation for the purpose of in-situ uranium reduction, specially as related to the bioavailability of Fe(III) phases. Key conclusions from this research include:

- Augmentation of Fe(III) via the addition of nanoparticulate ${ }^{57} \mathrm{Fe}$-goethite had a significant effect on the total flux of electrons towards different electron acceptors, it suppressed the degree of sulfate reduction, and it had no noticeable effect on the total uranium reduction.

- Most of the bacteria, including Geobacter-like species, contained high levels of ribosomes, indicating they were active and growing throughout the biostimulation time, including during times when sulfate reduction was the dominant TEAP. Hence, during biostimulation, biological iron reduction does occur concurrently with sulfate reduction, and the relative importance of each process is related to the bioavailability of $\mathrm{Fe}(\mathrm{III})$ phases. 
- During the second half of the experimental period, when the dominant TEAP was sulfate reduction, the numbers of Geobacter-like species increased near the column inflow, which coincided with an increased precipitation of uranium near the inflow.

- The microbiological analyses showed that there was a distinct separation between the microbial communities based on the two treatments (with and without ${ }^{57} \mathrm{Fe}$ goethite). They also showed an increasing differentiation within a column over time. This means that a slight increase in bioavailable Fe(III) does not only affect the overall electron flux to that electron acceptor, but also affects the microbial community structure. In all cases, the microbial diversity decreased during biostimulation.

Less acetate was utilized throughout the biostimulation period than what one would predict based on the stoichiometry of Fe(III) and sulfate reduction with acetate, and the measured decrease in sulfate and increase in Fe(II). This indicates that a significant mass of carbon is turned over rapidly and/or that in addition to biological iron reduction, a fraction of the Fe(III) is reduced abiotically with sulfide.

Overall these results suggest that it may be possible to manipulate microbial community structure and activity by amending with particulate Fe(III) oxides. Further research is warranted on transport of nanoparticulate Fe(III) particle in aquifers as a means of enhancing Fe reduction and suppressing sulfate reduction in uranium contaminated aquifers.

\section{Acknowledgments}

This research was funded by the Environmental Remediation Sciences Program (ERSP), Office of Biological and Environmental Research (OBER), U.S. Department of Energy (DOE), Pacific Northwest National Laboratory Project 51882 “The Rifle, Colorado Integrated Field Research Challenge Site (IFRC)”.

The Mössbauer analyses and SEM analysis were performed using Environmental Molecular Sciences Laboratory (EMSL), a national scientific user facility sponsored by the Department of Energy's Office of Biological and Environmental Research and located at Pacific Northwest National Laboratory. We would like to thank Bruce Arey (EMSL) for his help with SEM analysis.

\section{REFERENCES}

Abdelouas, A., Lutze, W., Nuttall, E., 1998. Chemical reactions of uranium in ground water at a mill tailings site. Journal of Contaminant Hydrology 34, 343-361.

Anderson, R.T., Vrionis, H.A., Ortiz-Bernad, I., Resch, C.T., Long, P.E., Dayvault, R., Karp, K., Marutzky, S., Metzler, D.R., Peacock, A., White, D.C., Lowe, M., Lovley, D.R., 2003. Stimulating the in situ activity of geobacter species to remove uranium from the groundwater of a uranium-contaminated aquifer. Applied and Environmental Microbiology 69, 5884-5891.

Bender, J., Duff, M.C., Phillips, P., Hill, M., 2000. Bioremediation and bioreduction of dissolved U(VI) by microbial mat consortium supported on silica gel particles. Environmental Science \& Technology 34, 3235-3241.

Berardesco, G., Dyhrman, S., Gallagher, E., Shiaris, M.P., 1998. Spatial and temporal variation of phenanthrene-degrading bacteria in intertidal sediments. Applied and Environmental Microbiology 64, 2560-2565.

Bosch, J., Heister, K., Hofmann, T., Meckenstock, R.U., 2009. Nanosized iron oxide colloids strongly enhance microbial iron reduction. Applied and Environmental Microbiology 76, 184-189.

Cardenas, E., Wu, W.M., Leigh, M.B., Carley, J., Carroll, S., Gentry, T., Luo, J., Watson, D., Gu, B., Ginder-Vogel, M., Kitanidis, P.K., Jardine, P.M., Zhou, J., Criddle, C.S., Marsh, T.L., Tiedje, J.A., 2008. Microbial communities in contaminated sediments, associated with bioremediation of uranium to submicromolar levels. Applied and Environmental Microbiology 74, 3718-3729.

Chapelle, F.H., Lovley, D.R., 1992. Competitive-exclusion of sulfate reduction by $\mathrm{Fe}(\mathrm{III})$-reducing bacteria - a mechanism for producing discrete zones of high-iron ground-water. GroundWater 30, 29-36.

Dong, H.L., Kukkadapu, R.K., Fredrickson, J.K., Zachara, J.M., Kennedy, D.W., Kostandarithes, H.M., 2003. Microbial reduction of structural $\mathrm{Fe}(\mathrm{III})$ in illite and goethite. Environmental Science \& Technology 37, 1268-1276.

Finneran, K.T., Anderson, R.T., Nevin, K.P., Lovley, D.R., 2002. Potential for Bioremediation of uranium-contaminated aquifers with microbial U(VI) reduction. Soil \& Sediment Contamination 11, 339-357.

Gallagher, E., McGuinness, L., Phelps, C., Young, L.Y., Kerkhof, L.J., $2005 .{ }^{13} \mathrm{C}$-carrier DNA shortens the incubation time needed to detect benzoate utilizing, denitrifying bacteria using stable isotope probing (SIP). Applied and Environmental Microbiology 71, 5192-5196.

Gorby, Y.A., Lovley, D.R., 1992. Enzymatic uranium precipitation. Environmental Science \& Technology 26, 205-207.

Gu, B.H., Yan, H., Zhou, P., Watson, D.B., Park, M., Istok, J., 2005. Natural humics impact uranium bioreduction and oxidation. Environmental Science \& Technology 39, 5268-5275.

Holmes, D.E., O'Neil, R.A., Vrionis, H.A., N'Guessan, L.A., OrtizBernad, I., Larrahondo, M.J., Adams, L.A., Ward, J.A., Nicoll, J.S., Nevin, K.P., Chavan, M.A., Johnson, J.P., Long, P.E., Lovley, D.R., 2007. Subsurface clade of Geobacteraceae that predominates in a diversity of $\mathrm{Fe}(\mathrm{III})$-reducing subsurface environments. The ISME Journal 1, 663-677.

Istok, J.D., Senko, J.M., Krumholz, L.R., Watson, D., Bogle, M.A., Peacock, A., Chang, Y.J., White, D.C., 2004. In situ bioreduction of technetium and uranium in a nitrate-contaminated aquifer. Environmental Science \& Technology 38, 468-475.

Karr, E.A., Sattley, W.M., Rice, M.R., Jung, D.O., Madigan, M.T., Achenbach, L.A., 2005. Diversity and distribution of sulfatereducing bacteria in permanently frozen Lake Fryxell, McMurdo Dry Valleys, Antarctica. Applied and Environmental Microbiology 71, 6353-6359.

Kerkhof, L., Kemp, P., 1999. Small ribosomal RNA content in marine Proteobacteria during non-steady-state growth. Fems Microbiology Ecology 30, 253-260.

Kerkhof, L., Ward, B.B., 1993. Comparison of nucleic acid hybridization and fluorometry for measurement of the relationship between RNA/DNA. Applied and Environmental Microbiology 59, 1303-1309.

Kindred, J.S., Celia, M.A., 1989. Contaminant transport and biodegradation .2. Conceptual-model and test simulations. Water Resources Research 25, 1149-1159.

Komlos, J., Mishra, B., Lanzirotti, A., Myneni, S.C.B., Jaffe, P.R., 2008a. Real-time speciation of uranium during active bioremediation and U(IV) reoxidation. Journal of Environmental Engineering-Asce 134, 78-86. 
Komlos, J., Moon, H.S., Jaffe, P.R., 2008b. Effect of sulfate on the simultaneous bioreduction of iron and uranium. Journal of Environmental Quality 37, 2058-2062.

Komlos, J., Peacock, A., Kukkadapu, R.K., Jaffe, P.R., 2008c. Longterm dynamics of uranium reduction/reoxidation under low sulfate conditions. Geochimica Et Cosmochimica Acta 72, 3603-3615.

Kukkadapu, R.K., Zachara, J.M., Fredrickson, J.K., Kennedy, D.W., 2004. Biotransformation of two-line silica-ferrihydrite by a dissimilatory $\mathrm{Fe}(\mathrm{III})$-reducing bacterium: formation of carbonate green rust in the presence of phosphate. Geochimica Et Cosmochimica Acta 68, 2799-2814.

Kukkadapu, R.K., Zachara, J.M., Fredrickson, J.K., McKinley, J.P., Kennedy, D.W., Smith, S.C., Dong, H.L., 2006. Reductive biotransformation of $\mathrm{Fe}$ in shale-limestone saprolite containing $\mathrm{Fe}(\mathrm{III})$ oxides and $\mathrm{Fe}(\mathrm{II}) / \mathrm{Fe}(\mathrm{III})$ phyllosilicates. Geochimica Et Cosmochimica Acta 70, 3662-3676.

Kukkadapu, R.K., Zachara, J.M., Smith, S.C., Fredrickson, J.K., Liu, C.X., 2001. Dissimilatory bacterial reduction of Alsubstituted goethite in subsurface sediments. Geochimica Et Cosmochimica Acta 65, 2913-2924.

Lack, J.G., Chaudhuri, S.K., Kelly, S.D., Kemner, K.M., O'Connor, S. M., Coates, J.D., 2002. Immobilization of radionuclides and heavy metals through anaerobic bio-oxidation of Fe(II). Applied and Environmental Microbiology 68, 2704-2710.

Lloyd, J.R., Lovley, D.R., 2001. Microbial detoxification of metals and radionuclides. Current Opinion in Biotechnology 12, 248-253.

Lovley, D.R., Phillips, E.J.P., 1987a. Competitive mechanisms for inhibition of sulfate reduction and methane production in the zone of ferric iron reduction in sediments. Applied and Environmental Microbiology 53, 2636-2641.

Lovley, D.R., Phillips, E.J.P., 1987b. Rapid assay for microbially reducible ferric iron in aquatic sediments. Applied and Environmental Microbiology 53, 1536-1540.

Lovley, D.R., Phillips, E.J.P., 1992. Reduction of uranium by desulfovibrio desulfuricans. Applied and Environmental Microbiology 58, 850-856.

McGuinness, L.M., Salganik, M., Vega, L., Pickering, K.D., Kerkhof, L.J., 2006. Replicability of bacterial communities in denitrifying bioreactors as measured by PCR/T-RFLP analysis. Environmental Science \& Technology 40, 509-515.

Mohanty, S.R., Kollah, B., Hedrick, D.B., Peacock, A.D., Kukkadapu, R.K., Roden, E., 2008. Biogeochemical process in ethanol stimulated uranium-contaminated subsurface sediments. Environmental Science \& Technology 42, 4384-4390.

Moon, H.S., Komlos, J., Jaffe, P.R., 2007. Uranium reoxidation in previously bioreduced sediment by dissolved oxygen and nitrate. Environmental Science \& Technology 41, 4587-4592.

Moon, H.S., Komlos, J., Jaffe, P.R., 2009. Biogenic U(IV) oxidation by dissolved oxygen and nitrate in sediment after prolonged $U$ (VI)/Fe(III)/SO ${ }_{4}^{2-}$ reduction. Journal of Contaminant Hydrology 105, 18-27.

Murad, E., Cashion, J., 2004. Mössbauer Spectroscopy of Environmental Materials and Their Industrial Utilization. Kluwer Academic Publishers, Dordrecht.

Postma, D., Jakobsen, R., 1996. Redox zonation: equilibrium constraints on the $\mathrm{Fe}(\mathrm{III}) / \mathrm{SO}_{4}^{-}$reduction interface. Geochimica Et Cosmochimica Acta 60, 3169-3175.
Poulton, S.W., 2003. Sulfide oxidation and iron dissolution kinetics during the reaction of dissolved sulfide with ferrihydrite. Chemical Geology 202, 79-94.

Poulton, S.W., Krom, M.D., Raiswell, R., 2004. A revised scheme for the reactivity of iron (oxyhydr)oxide minerals towards dissolved sulfide. Geochimica Et Cosmochimica Acta 68, 3703-3715.

Qafoku, N.P., Kukkadapu, R.K., McKinley, J.P., Arey, B.W., Kelly, S.D., Wang, C.M., Resch, C.T., Long, P.E., 2009. Uranium in framboidal pyrite from a naturally bioreduced alluvial sediment. Environmental Science \& Technology 43, 8528-8534.

Rabouille, C., Gaillard, J.F., 1991. A coupled model representing the deep-sea organic-carbon mineralization and oxygenconsumption in surficial sediments. Journal of Geophysical Research-Oceans 96, 2761-2776.

Riley, R.G., Zachara, J.M., Wobber, F.J., 1992. Chemical Contaminants on DOE Lands and Selection of Contaminant Mixtures for Subsurface Science Research. U.S. Department of Energy, Washington, DC.

Sani, R.K., Peyton, B.M., Amonette, J.E., Geesey, G.G., 2004. Reduction of uranium(VI) under sulfate-reducing conditions in the presence of $\mathrm{Fe}(\mathrm{III})$-(hydr)oxides. Geochimica Et Cosmochimica Acta 68, 2639-2648.

Schwertmann, U., Cornell, R.M., 1991, first ed. Iron Oxides in the Laboratory: Preparation and Characterization Wiley-VCH.

Smith, S.L., Jaffe, P.R., 1998. Modeling the transport and reaction of trace metals in water-saturated soils and sediments. Water Resources Research 34, 3135-3147.

Stults, J.R., Snoeyenbos-West, O., Methe, B., Lovley, D.R., Chandler, D.P., 2001. Application of the 5' fluorogenic exonuclease assay (TaqMan) for quantitative ribosomal DNA and rRNA analysis in sediments. Appl Environ Microb 67, 2781-2789.

Suzuki, M.T., Taylor, L.T., DeLong, E.F., 2000. Quantitative analysis of small-subunit rRNA genes in mixed microbial populations via 5'-nuclease assays. Appl Environ Microb 66, 4605-4614.

van der Zee, C., Roberts, D.R., Rancourt, D.G., Slomp, C.P., 2003. Nanogoethite is the dominant reactive oxyhydroxide phase in lake and marine sediments. Geology 31, 993-996.

Vrionis, H.A., Anderson, R.T., Ortiz-Bernad, I., O'Neill, K.R., Resch, C.T., Peacock, A.D., Dayvault, R., White, D.C., Long, P.E., Lovley, D.R., 2005. Microbiological and geochemical heterogeneity in an in situ uranium bioremediation field site. Applied and Environmental Microbiology 71, 6308-6318.

Wang, S., Jaffe, P.R., Li, G., Wang, S.W., Rabitz, H.A., 2003. Simulating bioremediation of uranium-contaminated aquifers; uncertainty assessment of model parameters. Journal of Contaminant Hydrology 64, 283-307.

Wu, W.M., Carley, J., Fienen, M., Mehlhorn, T., Lowe, K., Nyman, J., Luo, J., Gentile, M.E., Rajan, R., Wagner, D., Hickey, R.F., Gu, B. H., Watson, D., Cirpka, O.A., Kitanidis, P.K., Jardine, P.M., Criddle, C.S., 2006. Pilot-scale in situ bioremediation of uranium in a highly contaminated aquifer. 1. Conditioning of a treatment zone. Environmental Science \& Technology 40, 3978-3985.

Yabusaki, S.B., Fang, Y., Long, P.E., Resch, C.T., Peacock, A.D., Komlos, J., Jaffe, P.R., Morrison, S.J., Dayvault, R.D., White, D.C., Anderson, R.T., 2007. Uranium removal from groundwater via in situ biostimulation: field-scale modeling of transport and biological processes. Journal of Contaminant Hydrology 93, 216-235. 